\title{
Tissue Engineering of Cartilage Using a Random Positioning Machine
}

\author{
Markus Wehland ${ }^{1, *(\mathbb{D})}$, Paul Steinwerth ${ }^{1}$, Ganna Aleshcheva ${ }^{1}$, Jayashree Sahana ${ }^{2}$, \\ Ruth Hemmersbach ${ }^{3}$, Ronald Lützenberg ${ }^{1}$, Sascha Kopp ${ }^{1}{ }^{\mathbb{D}}$, Manfred Infanger ${ }^{1}$ and \\ Daniela Grimm ${ }^{1,2}$ \\ 1 Department of Microgravity and Translational Regenerative Medicine, Clinic for Plastic, Aesthetic and \\ Hand Surgery, Otto von Guericke University, 39106 Magdeburg, Germany; paul.steinwerth@st.ovgu.de (P.S.); \\ anna_alestheva@yahoo.de (G.A.); ronald.luetzenberg@med.ovgu.de (R.L.); sascha.kopp@med.ovgu.de (S.K.); \\ manfred.infanger@med.ovgu.de (M.I.); daniela.grimm@med.ovgu.de (D.G.) \\ 2 Department for Biomedicine, Aarhus University, 8000 Aarhus, Denmark; jaysaha@biomed.au.dk \\ 3 Gravitational Biology, Institute of Aerospace Medicine, German Aerospace Center, 51147 Cologne, Germany; \\ ruth.hemmersbach@dlr.de \\ * Correspondence: markus.wehland@med.ovgu.de
}

Received: 5 November 2020; Accepted: 14 December 2020; Published: 16 December 2020

check for updates

\begin{abstract}
Articular cartilage is a skeletal tissue of avascular nature and limited self-repair capacity. Cartilage-degenerative diseases, such as osteoarthritis (OA), are difficult to treat and often necessitate joint replacement surgery. Cartilage is a tough but flexible material and relatively easy to damage. It is, therefore, of high interest to develop methods allowing chondrocytes to recolonize, to rebuild the cartilage and to restore joint functionality. Here we studied the in vitro production of cartilage-like tissue using human articular chondrocytes exposed to the Random Positioning Machine (RPM), a device to simulate certain aspects of microgravity on Earth. To screen early adoption reactions of chondrocytes exposed to the RPM, we performed quantitative real-time PCR analyses after $24 \mathrm{~h}$ on chondrocytes cultured in DMEM/F-12. A significant up-regulation in the gene expression of IL6, RUNX2, RUNX3, SPP1, SOX6, SOX9, and MMP13 was detected, while the levels of IL8, ACAN, PRG4, ITGB1, TGFB1, COL1A1, COL2A1, COL10A1, SOD3, SOX5, MMP1, and MMP2 mRNAs remained unchanged. The STRING (Search Tool for the Retrieval of Interacting Genes/Proteins) analysis demonstrated among others the importance of these differentially regulated genes for cartilage formation. Chondrocytes grown in DMEM/F-12 medium produced three-dimensional (3D) spheroids after five days without the addition of scaffolds. On day 28 , the produced tissue constructs reached up to $2 \mathrm{~mm}$ in diameter. Using specific chondrocyte growth medium, similar results were achieved within 14 days. Spheroids from both types of culture media showed the typical cartilage morphology with aggrecan positivity. Intermediate filaments form clusters under RPM conditions as detected by vimentin staining after $7 \mathrm{~d}$ and $14 \mathrm{~d}$. Larger meshes appear in the network in 28-day samples. Furthermore, they were able to form a confluent chondrocyte monolayer after being transferred back into cell culture flasks in $1 \mathrm{~g}$ conditions showing their suitability for transplantation into joints. Our results demonstrate that the cultivation medium has a direct influence on the velocity of tissue formation and tissue composition. The spheroids show properties that make them interesting candidates for cellular cartilage regeneration approaches in trauma and OA therapy.
\end{abstract}

Keywords: tissue engineering; cartilage; spheroids; random positioning machine; scaffold-free

\section{Introduction}

Adult articular cartilage tissue has only a very limited ability for self-regeneration owing to its low vascularization and cell density [1]. Therefore, even minor lesions may lead to progressive 
damage and degeneration (osteoarthritis $(\mathrm{OA})$, cartilage trauma). The incidence of these disorders is steadily increasing. In the U.S. alone, more than 70 million patients suffer from articular cartilage injuries caused mainly by OA, generating an estimated economic burden of about $\$ 100$ billion by 2020, as the elderly population continues to grow [2]. Three-dimensional (3D) cell culture techniques have therefore attracted much attention among clinicians interested in tissue engineering as a novel approach for cartilage repair.

Chondrocytes are able to produce, maintain, and remodel the cartilage extracellular matrix (ECM) in vitro [3]. However, chondrocyte expansion in monolayer cultures causes cell dedifferentiation and loss of their original phenotype after more than four rounds of subculture [4]. In most cartilage tissue engineering studies, chondrocytes from immature animals are used. These proliferate faster and have an increased chondrogenic potential compared to the cells from older animals or human donors, which are metabolically less active in vitro [5]. These limitations can partly be counteracted with altered culture conditions such as usage of rotating bioreactors [6], culture in serum-free media [7], growth under reduced oxygen tension [8], and the addition of growth factors [9]. However, unlike bone, cartilage regeneration using tissue engineering strategies has not yet been successful in precisely recreating cartilage which was both structurally and functionally equivalent to in vivo tissue [10].

Cell culture systems including spinner flasks, rotating bioreactors, and perfusion (flow-through) bioreactors have already been successfully applied for cartilage tissue engineering [11]. Bioreactors offer several important advantages over simple tissue-flask and Petri-dish culture systems. Bioreactors provide enhanced mass transfer by convective fluid flow, the ability to provide mechanical forces influencing tissue development, and a better control over culture conditions. In most of the cases, cartilage development is achieved in vitro by cultivating chondrocytes on biodegradable polymer scaffolds. These scaffolds provide an environment in which cells can proliferate, function, secrete proteins, and organize into a tissue that resembles natural cartilage in important respects [12]. The ideal scaffold should be biodegradable without exerting cytotoxic, tumorigenic, nephrotoxic or other undesirable effects; have a porosity that allows for diffusion of nutrients and waste products; support cell viability, proliferation, differentiation and ECM production; be able to attach to and integrate into the tissue at the defect site; and provide mechanical support $[1,3]$. This is very hard to achieve. Moreover, problems such as necrosis due to high-density cell culture and shear stress have not yet been solved using conventional stirred fermenters [4].

The number of cells that can be isolated from a clinical biopsy is not sufficient for cell-based therapies such as autologous cartilage implantation. Thus, an expansion of the chondrocytes is necessary. This is usually achieved in monolayer cell culture which potentially reduces their chondrogenic capacities [13]. This is especially problematic for scaffold-free methods that rely on the volume of cells to act as their own mechanical support [6].

The Random Positioning Machine (RPM) is a device that was developed to simulate certain aspects of microgravity $(\mu g)$ on Earth. It consists of two perpendicular and independently driven frames, which enable the rotation of a sample mounted to the center of the inner frame around all three axes in space, essentially providing a spherical rotational freedom [14]. This setup can be used as a 3D clinostat, driving both frames with constant directions and speeds, or as an RPM, randomly varying both speed and direction. For a sufficiently small rotated sample (such as human cells) the direction of the gravity vector will constantly change, and over time it will be averaged to almost zero [14]. The RPM was used with different cell types, and it could be shown that the altered gravity conditions favored the development of 3D-structures such as spheroids from thyroid cancer cells [15,16], duct-like constructs from breast cancer cells [17], 3D clusters from chondrocytes [18] and, most strikingly, intima-like tubular structures from endothelial cells [19]. Using the RPM might therefore allow a reduction in the number of cells, and the prefabrication of implants without the complications associated with scaffolds.

The objective of the present study was to demonstrate scaffold-free cartilage tissue formation from cryogenically preserved human chondrocytes. For this purpose, human articular chondrocytes were cultured for $7,14,21$, and 28 days in two different media on the RPM running in the real 
random mode. After each time point, the spheroid production was investigated both macroscopically and microscopically to assess cell morphology and to determine the amount and distribution of cartilage-specific tissue components. Furthermore, quantitative real-time PCR (qPCR) analyses were conducted to investigate the expression of key genes involved in cartilage production.

\section{Results}

\subsection{Chondrocyte Morphology Depends on the Cultivation Medium}

The cells responded differently to each medium tested. In the first passage, the chondrocytes cultivated in Dulbecco's Modified Eagle Medium (DMEM)/F-12 medium and in chondrocyte growth medium (CGM), each supplemented with 10\% fetal calf serum (FCS), displayed features of the chondrogenic phenotype; i.e., they were spherical, slowly proliferating, and formed colonies (Figure 1a,b).

Already after four rounds of subculture, the cells cultivated in both media showed abnormal morphology. They appeared dedifferentiated and formed a squamous eddy-like structure. We detected many rapidly growing fibroblast-like, star-shaped cells with a foamy, vacuolated cytoplasm (Figure 1c,d).
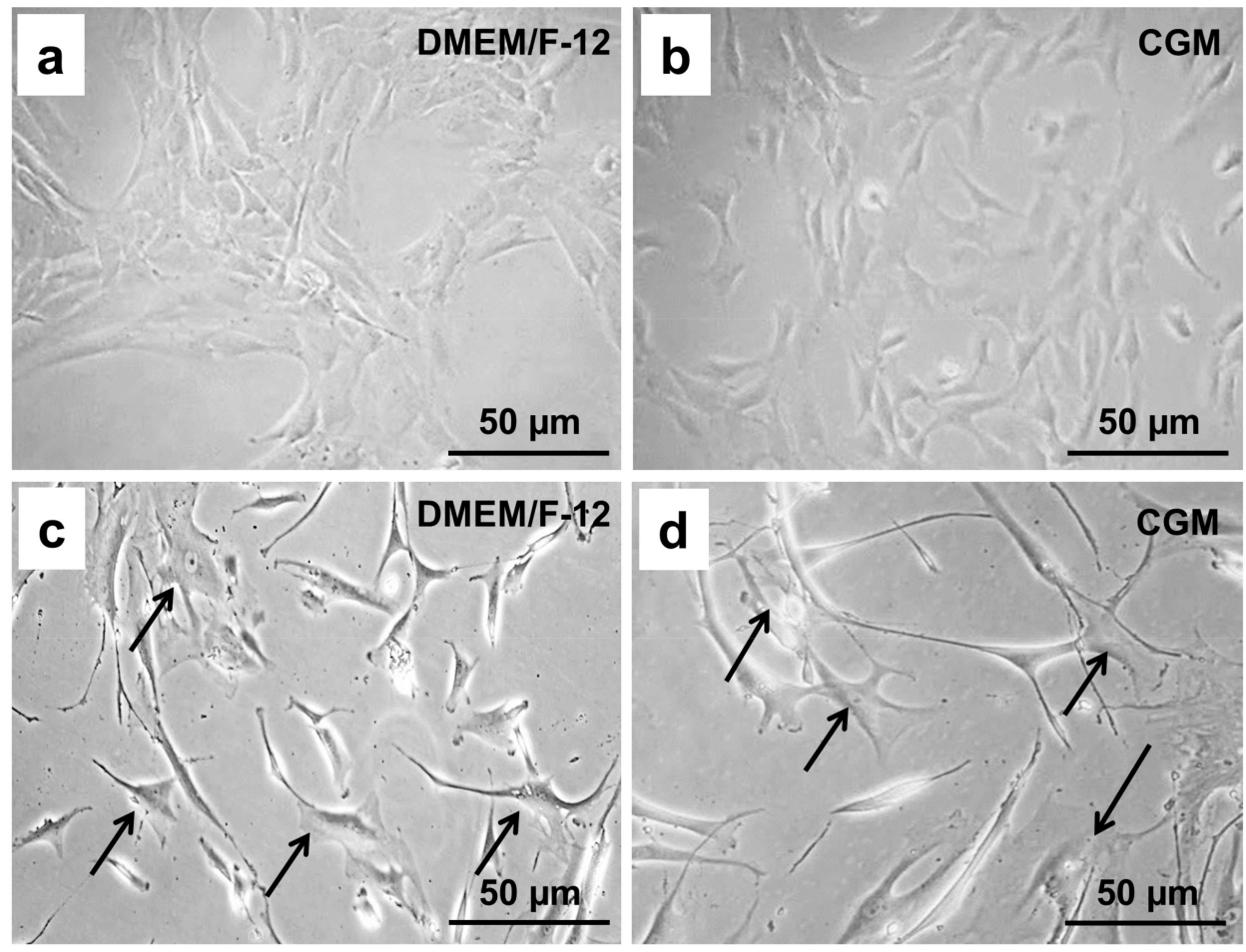

Figure 1. Morphological characteristics of human chondrocytes visualized by phase contrast microscopy. (a) Human chondrocytes cultivated in DMEM/F-12 medium after the first round of subculture. (b) Human chondrocytes cultivated in CGM after the first round of subculture. (c) Human chondrocytes cultivated in DMEM/F-12 medium after a third round of subculture. (d) Human chondrocytes cultivated in CGM after a third round of subculture. The arrows indicate the cell bodies of fibroblast-like single cells.

\subsection{Chondrocytes Change Their Cellular Structure during Cultivation}

The chondrocytes are ovoid cells ranging in maximum diameter from about $10 \mu \mathrm{m}$ in articular cartilage to about $30 \mu \mathrm{m}$ in other hyaline cartilages [20] (Figure 2a). The cell has a scalloped surface (Figure 2a,b). The pericellular matrix is usually of a finer texture than the coarsely extracellular matrix 
more remote from the cell (Figure 2b). The junction is often sharply demarcated and constitutes the lacunar rim. The cell nucleus in older chondrocytes is often irregular (Figure 2c).

After endocytosis, the digestion of partly degraded macromolecules is completed in the lysosomal vacuole [21] with complete breakdown of the ECM around the cells (Figure 2c). Mitochondria are quite numerous in chondrocytes of immature tissue but in the adult become scarcer, smaller, and dense with few cristae (Figure 2c). This is in accord with the low respiratory activity of chondrocytes. However, in the growth plate, mitochondria are often the only organelles that are well-preserved. Moreover, prolonged cultivation resulted in cell edema, disturbing physiological processes, and doubling of the chondrocytes (Figure 2d).

Glycogens and lipids are common inclusions of the chondrocyte (Figure 2e-h). The large amounts of lipid in chondrocytes have never been explained satisfactorily. Fat is a normal inclusion, but there is little evidence that it is used either by the cell itself or by the whole organism. Fat globules increase in size during maturation and prolonged cultivation (Figure 2e-h) and are smaller in articular than other hyaline cartilages.
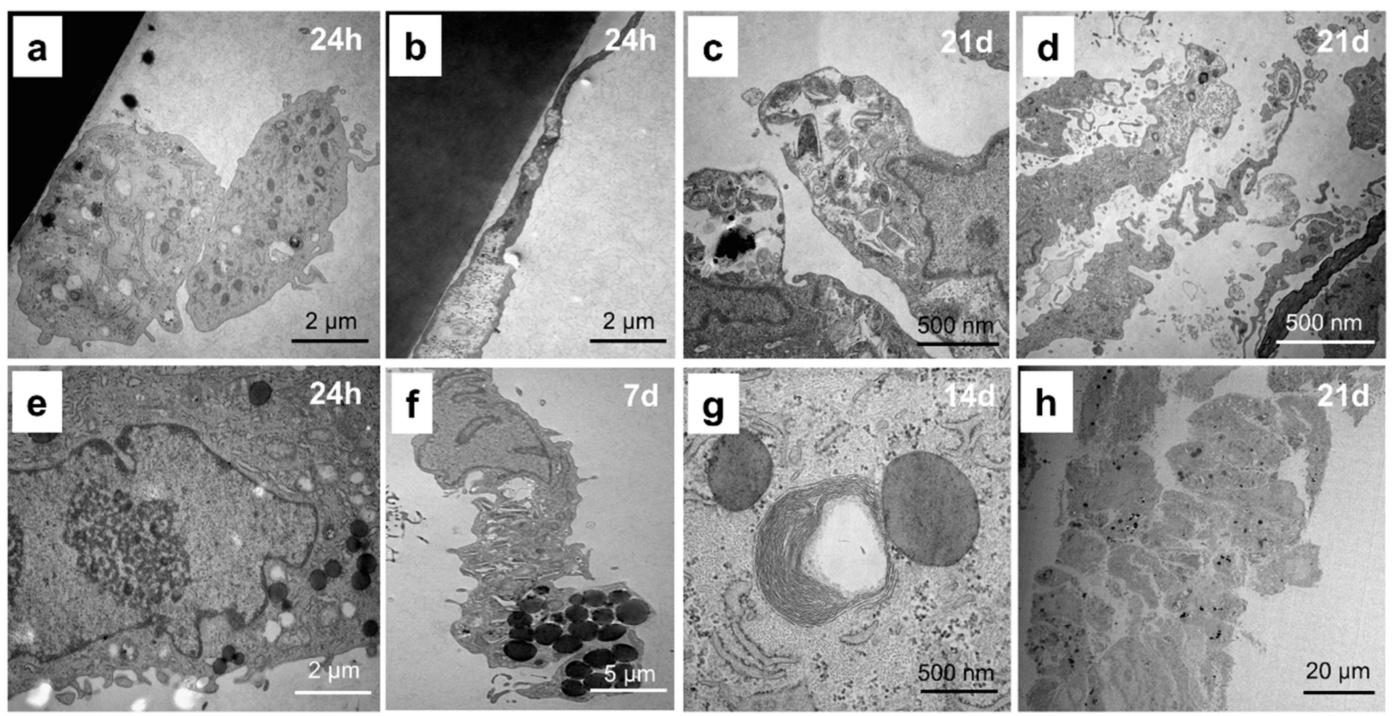

Figure 2. Morphological characteristics of chondrocytes analyzed by transmission electron microscopy. (a) Two chondrocytes cultivated for $24 \mathrm{~h}$ in DMEM/F-12 medium. (b) Partially edematous cytoplasm of chondrocytes cultivated for $24 \mathrm{~h}$ in DMEM/F-12 medium. (c) Chondrocytes undergoing autolysis during the cultivation for $21 \mathrm{~d}$ in DMEM/F-12 medium. (d) Cell edema after the cultivation for $21 \mathrm{~d}$ in DMEM/F-12 medium. (e) Cell lipids (black spots) visible after the cultivation for $24 \mathrm{~h}$ in DMEM/F-12 medium. (f) Cell lipids (black spots) visible after the cultivation for $7 \mathrm{~d}$ in DMEM/F-12 medium. (g) Cell lipids (black spots) visible after the cultivation for $14 \mathrm{~d}$ in DMEM/F-12 medium. (h) Cell lipids (black spots) visible after the cultivation for $21 \mathrm{~d}$ in DMEM/F-12 medium.

\subsection{4-h Short-Term Gene Expression Changes on the RPM}

To screen early adoption reactions of chondrocytes to the culture conditions on the RPM, we performed quantitative real-time PCR analyses after $24 \mathrm{~h}$ on chondrocytes cultured in DMEM/F-12. We focused on A: IL6, B: IL8, C: ACAN, D: PRG4, E: RUNX2, F: RUNX3, G: ITGB1, H: TGFB1, I: COL1A1, J: COL2A1, K: COL10A1, L: SOD3, M: SPP1, N: SOX5, O: SOX6, P: SOX9, Q: MMP1, R: MMP2, and S: MMP13 (Figure 3). We found significant increases in the gene expressions of IL6, RUNX2, RUNX3, SPP1, SOX6, SOX9, and MMP13, while IL8, ACAN, PRG4, ITGB1, TGFB1, COL1A1, COL2A1, COL10A1, SOD3, SOX5, MMP1, and MMP2 remained unchanged (Figure 3). No significant down-regulations were observed. 

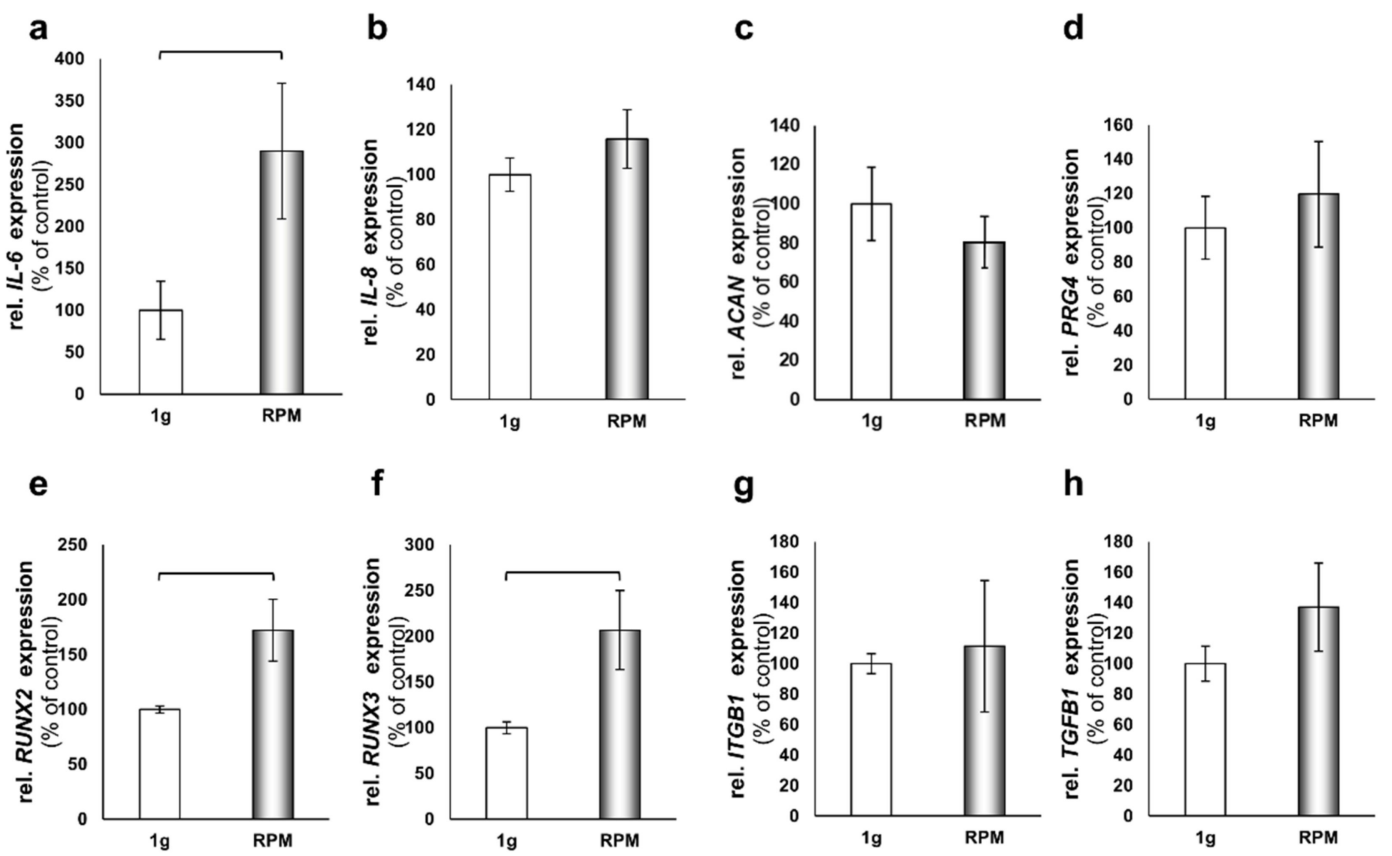

f

g

h
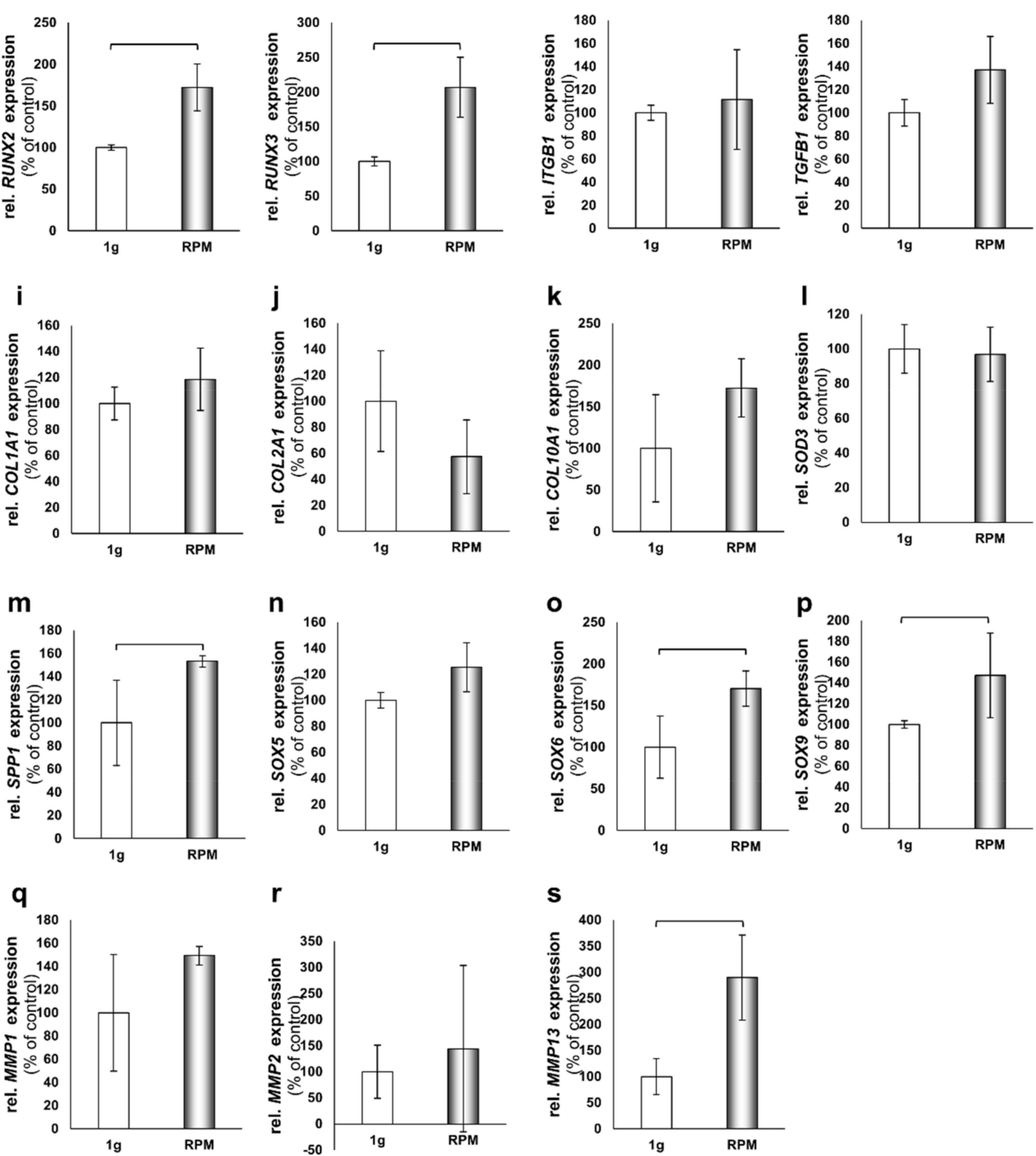

Figure 3. Quantitative real-time PCR analysis of cartilage-related genes. (a) IL6. (b) CXCL8 (IL8). (c) ACAN. (d) PRG4. (e) RUNX2. (f) RUNX3. (g) ITGB1. (h) TGFB1. (i) COL1A1. (j) COL2A1. (k) COL10A1. (1) SOD3. (m) SPP1. (n) SOX5. (o) SOX6. (p) SOX9. (q) MMP1. (r) MMP2. (s) MMP13. All analyses were done with chondrocytes cultivated in DMEM/F-12 medium for $24 \mathrm{~h}$ on the RPM. Static samples incubated beside the RPM inside the same incubator served as the $1 \mathrm{~g}$ controls. Brackets above the bars indicate significant changes ( $n=5$ each group: $1 g$ and RPM), significance $p<0.05$ ). 


\subsection{Chondrocytes Produce Spheroids on the RPM up to $2 \mathrm{~mm}$ in Size}

After $7 \mathrm{~d}$ of sustained cultivation on the RPM in DMEM/F-12, we detected the formation of 3D spheroids (Figure 4a). Over the course of the experiment, the spheroids increased in size (Figure 4b,c) and reached about $1 \mathrm{~mm}$ in diameter after $28 \mathrm{~d}$ (Figure $4 \mathrm{~d}$ ).
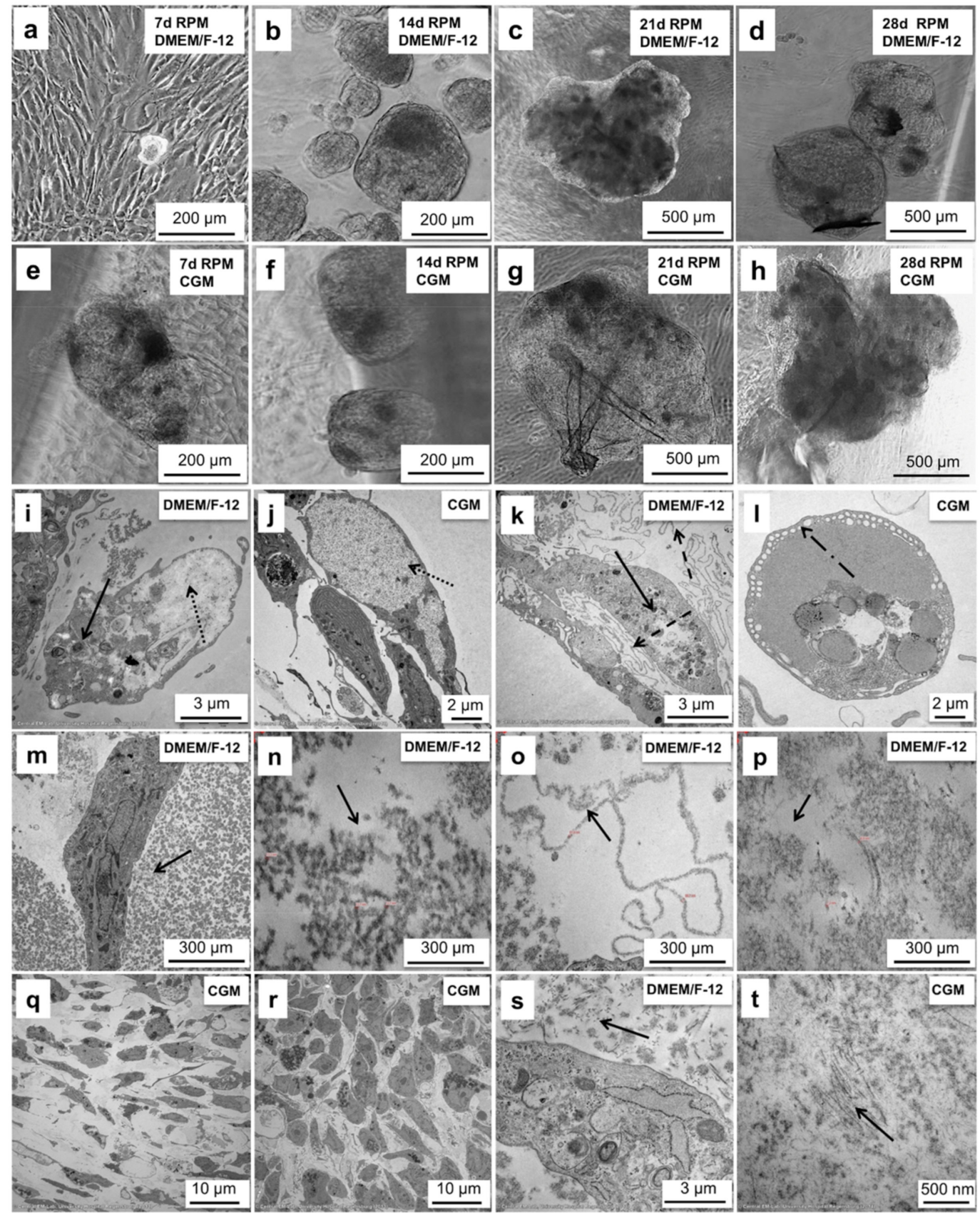

Figure 4. Morphological characterization of spheroids produced from articular chondrocytes on the RPM. (a) Spheroids produced during the 7-day-cultivation in DMEM/F-12 medium (b) Spheroids produced during the cultivation for 14 days in DMEM/F-12 medium. (c) Spheroids produced during the 21-day-cultivation in DMEM/F-12 medium. (d) Spheroids produced during the cultivation for 28 days in DMEM/F-12 medium. (e) Spheroids produced during the cultivation for 7 days in CGM medium. (f) Spheroids produced during the cultivation for 14 days in CGM medium. (g) Spheroids produced during the 21-day-cultivation in CGM medium. (h) Spheroids produced during the cultivation for 28 days in CGM medium. (i) Accumulation of glycogen (dotted arrow) and lysosomes (solid arrow) 
in the cells composing spheroid produced during the 28-day-cultivation in DMEM/F-12 medium. (j) Accumulation of glycogen (dotted arrow) in the cells composing spheroid produced during the 28-day-cultivation in CGM medium. (k) Cell edema (dashed arrow) and lipid (solid arrow) accumulation in the cells of the spheroid produced during the 28-day-cultivation in DMEM/F-12 medium. (1) Pinocytotic activity (dashed arrow) of the cells inside the spheroid produced during the 28-day-cultivation in CGM medium. (m) Granular clusters (arrow) of the material inside the spheroid produced during the 28-day-cultivation in DMEM/F-12 medium. (n) Variable long "zigzag"-forming filaments (arrow) inside the spheroid produced during the $28 \mathrm{~d}$ cultivation in DMEM/F-12 medium. (o) Loop organized structures (arrow) inside the spheroid produced during the $28 \mathrm{~d}$ cultivation in DMEM/F-12 medium. (p) Multifocal interspersed fine filament structures (arrow) inside the spheroid produced during the 28-day-cultivation in DMEM/F-12 medium. (q) Elongated cells on the surface of the spheroid formed during the 28-day-cultivation in CGM. (r) Round-shaped cells inside the spheroid formed during the 28-day-cultivation in CGM. (s) Collagen II bundles (arrow) inside the spheroid produced during the 28-day-cultivation in DMEM/F-12 medium. ( $\mathbf{t}$ ) Collagen II bundles (arrow) inside the spheroid produced during the 28-day-cultivation in CGM medium. Cells of passage 3 were used for the experiment.

Using CGM the spheroid production was detected already after $4 \mathrm{~d}$ of cultivation. After 7,14, and 21 days they were bigger than their counterparts grown in DMEM/F12. (Figure 4e-g). On day 28, the spheroids reached about $2 \mathrm{~mm}$ in diameter (Figure $4 \mathrm{~h}$ ).

\subsection{Chondrocyte Spheroids Have a Rich Morphology and Form Collagen Fibrils}

After $28 \mathrm{~d}$ of cultivation in DMEM/F-12 medium, we observed an accumulation of lysosomes (Figure 4i), spherical vesicles containing hydrolytic enzymes, which are capable of breaking down proteins, nucleic acids, carbohydrates, lipids, and cellular debris inside the spheroids. Lysosomes function in the removal of effete intracellular material that are also concerned with the turnover of the extracellular matrix in chondrocytes [22].

Moreover, the cells accumulated glycogen (Figure $4 \mathrm{i}, \mathrm{j}$ ), a common polysaccharide inclusion of the chondrocyte that serves as main energy storage form of glucose in the body. Glycogen may be one of many sources of organic phosphate for calcification in the epiphyseal growth plate providing the raw material for matrix synthesis [22].

After $28 \mathrm{~d}$ of sustained cultivation of chondrocytes on the RPM, we detected cell edema (Figure 4k), abnormal accumulation of fluid, and fat accumulation (Figure 4k). Among these fats, cholesterol, for example, protects membrane integrity/cell viability and thus is able to change the shape of the membrane and move about.

In the chondrocytes cultivated in DMEM/F-12, we detected pinocytosis (Figure 41), a mode of endocytosis used primarily for the absorption of extracellular fluids. Four different kinds of filaments have been detected in the conjunctive tissue of the spheroids (Figure 4m-p): (1) Granular clusters of the material looking like basement membranes (Figure 4m); (2) Variable long "zigzag" forming filaments (Figure 4n); (3) Loop-organized structures looking like basement membranes (Figure 4o); (4) Multifocal interspersed fine filament structures (Figure 4p). Most chondrocytes contain fine filaments 7-10 nm in diameter in the cytoplasm. Large masses of them are thought to be a sign of cell degeneration [23]. While actin-like filaments have been identified in cultured chondrocytes [24], the chemical nature of the $10 \mathrm{~nm}$ filaments is not known.

The cartilage-like tissue formed in CGM was composed of the cells of two different shapes-elongated (Figure $4 \mathrm{q}$ ) and round (Figure 4r). It is generally accepted that chondrocyte morphology changes are dependent upon the location within articular cartilage. Cells near the surface are ellipsoid and become spheroidal with depth into the middle and deep zones [25]. 
After $28 \mathrm{~d}$ the cells formed proto-collagen fibrils, one of the most important components of the cartilage (Figure $4 \mathrm{~s}, \mathrm{t}$ ). The fibrils are indeterminate in length and insoluble, and they form elaborate $3 \mathrm{D}$ arrays that extend over numerous cell lengths [26]. They have a distinctive $67 \mathrm{~nm}$ axial periodicity with a length in the range of several $\mathrm{mm}$ and range in diameter from a few to $500 \mathrm{~nm}$ (Figure 4t).

\subsection{Cytoskeletal Composition of Spheroid Changes with the Duration of the Cultivation Time}

It is now widely accepted that the cytoskeleton plays a role in sensing changes in gravity. It is composed of three types of protein networks: actin microfilaments, microtubules as represented by beta-tubulin staining, and intermediate filaments as represented by vimentin staining. Studies of the major components of the cytoskeleton in other cell types have shown that actin microfilaments play roles in a tremendous number of cellular events including migration [27], adhesion [28], shape alteration [29], cell signaling [30], and extracellular matrix assembly [31]. Under microgravity conditions, actin stress fibers are reduced in number, length, and thickness. Actin is often redistributed and has either a more perinuclear or more cortical localization [32], as shown by F-actin staining. The shape of the spheroids cultivated in DMEM/F-12 medium supplemented with 10\% FCS was round and cortically localized stress fibers were visible on days 7, 14 and 21 of cultivation (Figure 5a-c,e-g,i-k) and still visible at day 28 with higher staining intensity (Figure $5 d, h, l)$.

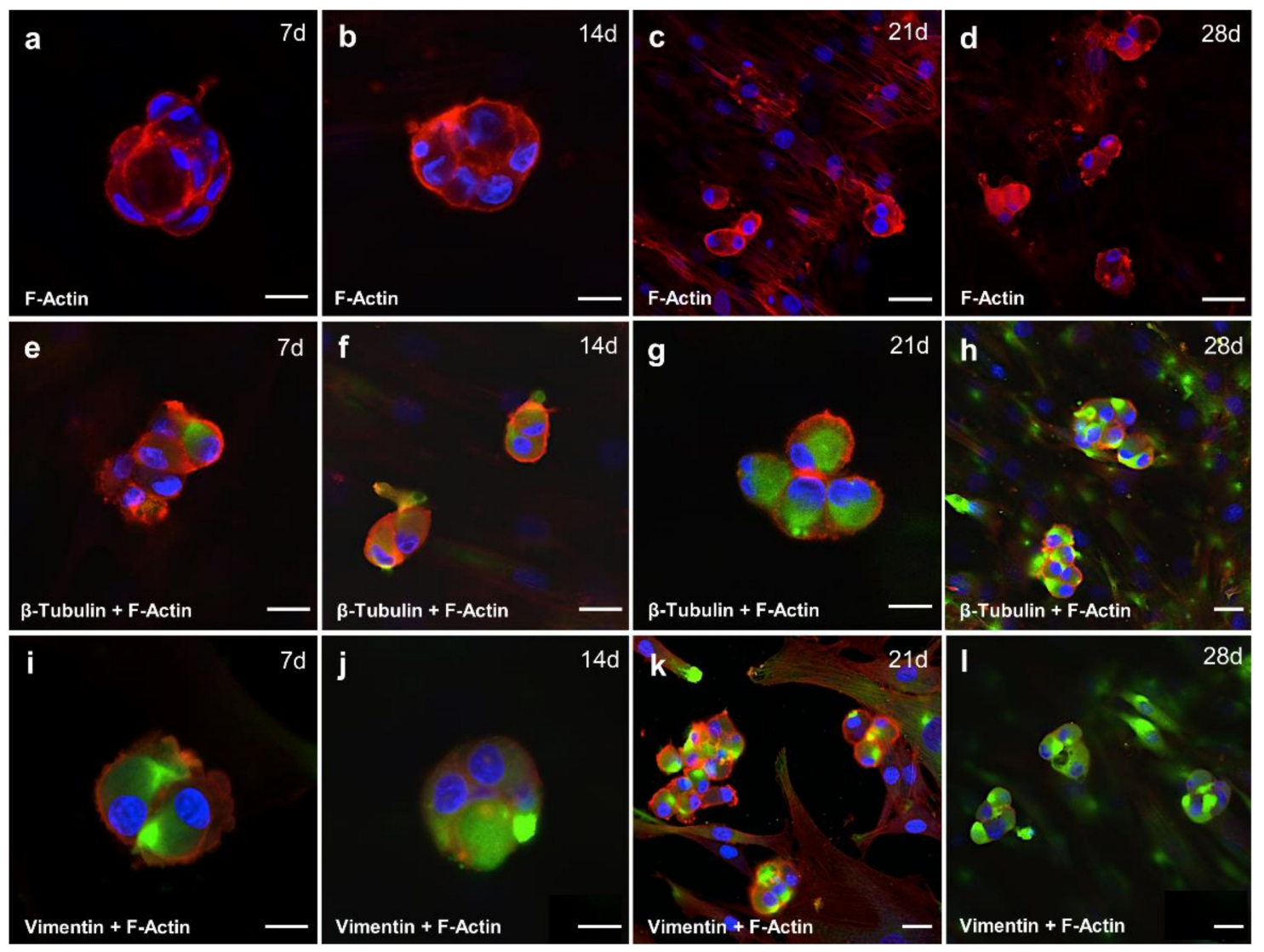

Figure 5. Cytoskeletal elements and arrangement in spheroids produced on the RPM. (a) F-Actin staining of spheroids produced during $7 \mathrm{~d}$, (b) $14 \mathrm{~d}$, (c) $21 \mathrm{~d}$ and (d) $28 \mathrm{~d}$ cultivation. (e) Immunofluorescence staining (IFS) of tubulin together with F-actin of spheroids produced during $7 \mathrm{~d}$, (f) $14 \mathrm{~d}$, (g) $21 \mathrm{~d}$ and (h) $28 \mathrm{~d}$ cultivation on the RPM. (i) IFS of vimentin together with F-actin of spheroids produced during $7 \mathrm{~d}$, (j) $14 \mathrm{~d}$, (k) $21 \mathrm{~d}$, (1) and during 28-day-cultivation on the RPM. Scale bars = $20 \mu \mathrm{m}$; red (rhodamine-phalloidin): F-actin, blue: Hoechst dye 33342-stained nuclei, green (FITC): tubulin or vimentin. 
As constantly renewing microtubules contribute to intracytoplasmic transport [33], mitotic spindle formation [34], and ciliary movement [35], and they can be up-regulated in chondrocyte hypertrophy [36]. Under microgravity conditions, microtubules lose their radial organization, and they can be shortened, more curved, and bent [32]. They are regularly localized more perinuclearly in cells exposed to real and simulated microgravity; this has been detected during our experiments already after $7 \mathrm{~d}$ of cultivation on the RPM (Figure $5 \mathrm{e}$ ). With the prolonged cultivation time, the staining intensity increased (Figure 5e-h).

Intermediate filaments were predominantly implicated in the mechanical integration of cellular space and in the spatial coordination of mechanical events [37] as well as signal transduction [38]. Intermediate filaments form clusters under simulated microgravity conditions as detected by the vimentin staining after $7 \mathrm{~d}$ (Figure 5i) and $14 \mathrm{~d}$ (Figure 5j). Moreover, larger meshes appear in the network, and the localization is more perinuclear [32], as detected on the 28th day (Figure 51).

\subsection{Cartilage-Like Tissue Reacts Positive Against Cartilage Markers and Produces Cartilage-Specific Proteins}

Morphological examination of sections of all produced tissue constructs from both cultivation media revealed differentiated chondrocytes ordered in clusters within a continuous dense cartilaginous matrix negative for collagen I (Figure $6 \mathrm{~b}, \mathrm{f})$ ), but strongly positive for collagen type II (Figure $6 c, \mathrm{~g}$ ) and aggrecan immunostaining (Figure 6d,h). Moreover, in the spheroids produced in DMEM/F-12 with prolonged cultivation time, we detected increased gene expression of aggrecan (Figure 6i) and collagen II (Figure 6k) compared to the control cells cultivated for $7 \mathrm{~d}$ under normal gravity conditions.

Interestingly, in the spheroids produced in CGM we detected the highest aggrecan (Figure 6j) and collagen type II (Figure 61) gene expression after $14 \mathrm{~d}$ of sustained cultivation. 


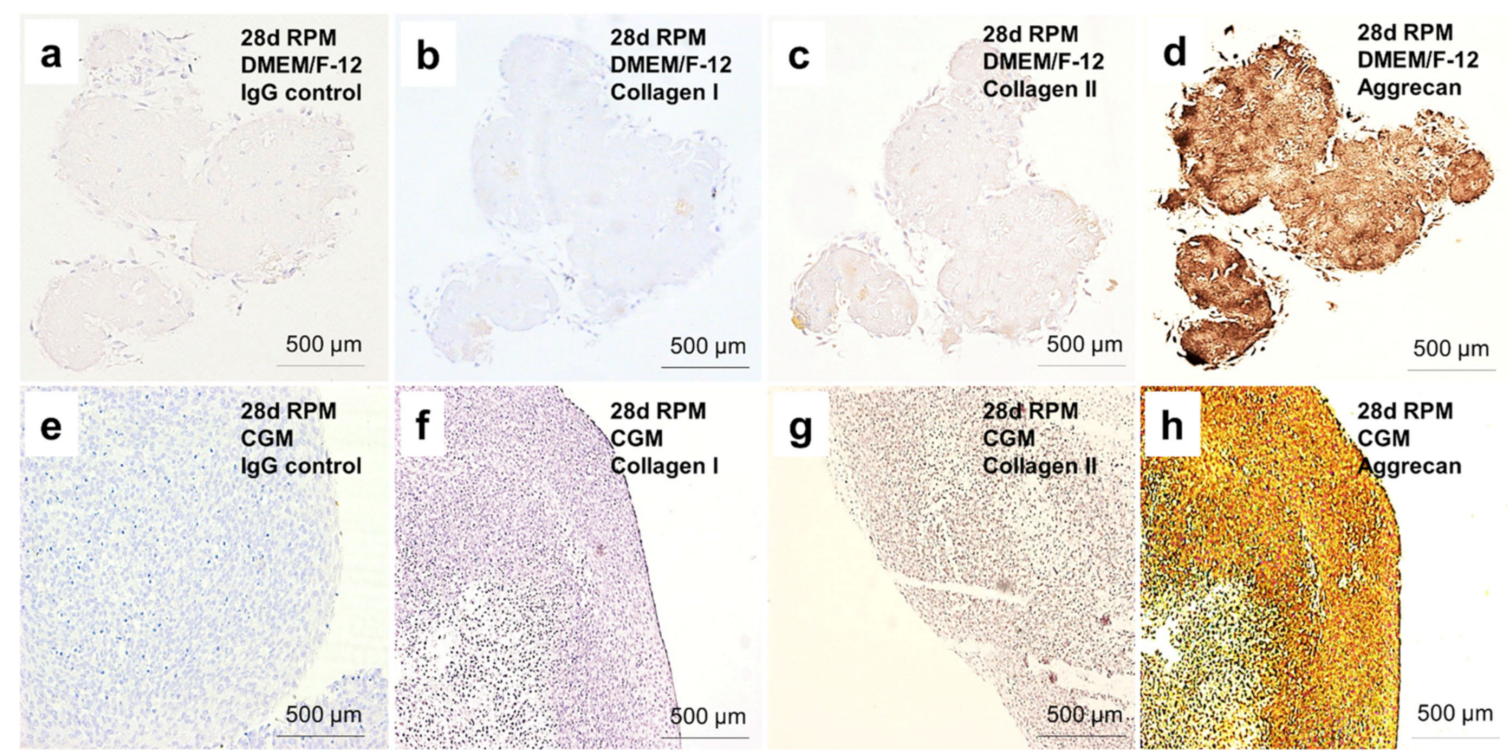

i
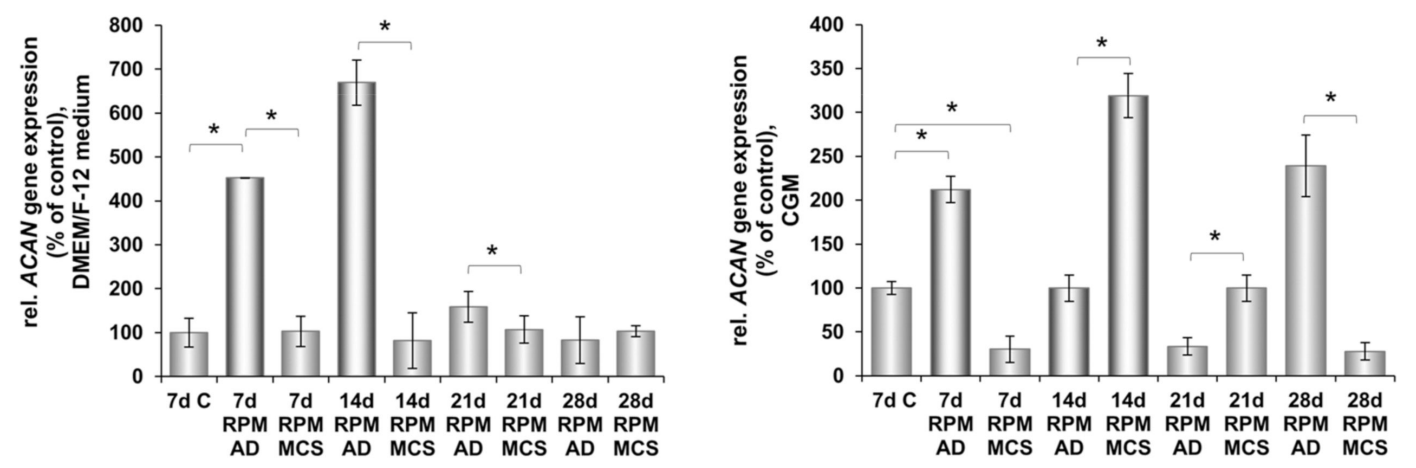

k

I
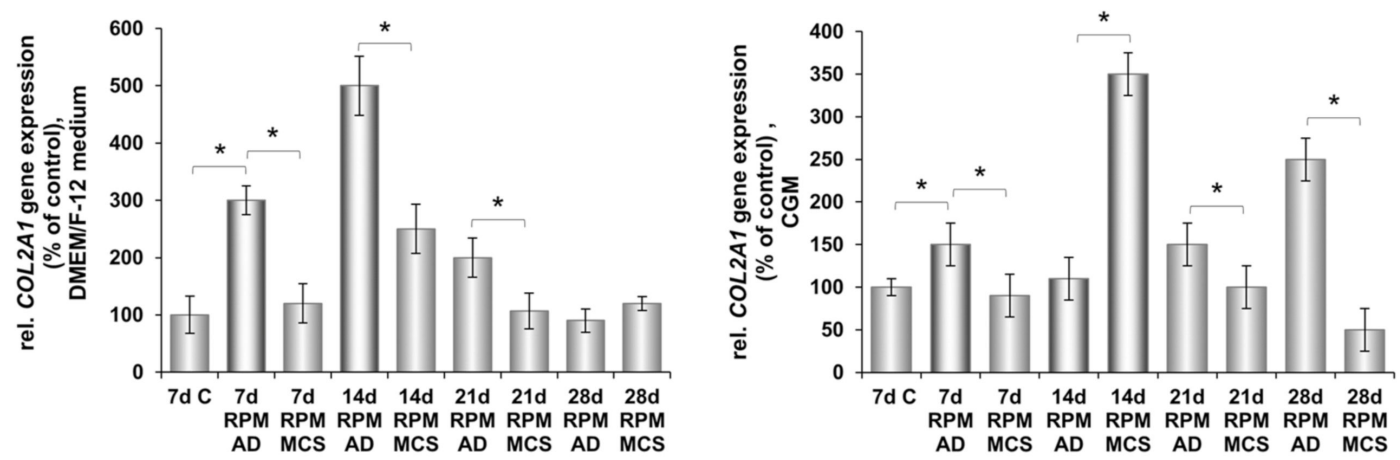

Figure 6. Identification and quantification of cartilage-specific components, using immunohistochemical staining and qPCR analyses. (a) Negative control of 28-day-old tissue produced in DMEM/F-12 medium stained only with the secondary antibody. (b) Immunohistochemical staining of 28-day-old spheroid produced in DMEM/F-12 medium with monoclonal antibody against collagen type I. (c) Monoclonal antibody against collagen type II, (d) Monoclonal antibody against aggrecan. (e) Negative control of 28-day-old tissue produced in CGM stained only with the secondary antibody. (f) Immunohistochemical staining of 28-day-old spheroid produced in CGM with monoclonal antibody against collagen type I, (g) with monoclonal antibody against collagen type II, and (h) with monoclonal antibody against aggrecan. (i) Relative gene expression of aggrecan in 7-day-old chondrocytes cultured under normal gravity conditions $(C)$, and in adherent cells (AD) and tissue (MCS) produced in DMEM/F-12 medium 
after $7 \mathrm{~d}, 14 \mathrm{~d}, 21 \mathrm{~d}$, and $28 \mathrm{~d}$ of RPM-exposure. (j) Relative gene expression of collagen type 2 in $\mathrm{C}, \mathrm{AD}$, and MCS produced in DMEM/F-12 medium after $7 \mathrm{~d}, 14 \mathrm{~d}, 21 \mathrm{~d}$, and $28 \mathrm{~d}$ of RPM-exposure. (k) Relative gene expression of aggrecan in C; AD, and MCS produced in CGM after $7 \mathrm{~d}, 14 \mathrm{~d}, 21 \mathrm{~d}$, and $28 \mathrm{~d}$ of RPM-exposure. (1) Relative gene expression of collagen type 2 in C; AD, and MCS produced in CGM after $7 \mathrm{~d}, 14 \mathrm{~d}, 21 \mathrm{~d}$, and $28 \mathrm{~d}$ of cultivation on the RPM. C: 7-day-old chondrocytes cultured under normal gravity conditions; AD: adherent cells on the RPM; MCS: 3D tissue constructs on the RPM. All qPCR experiments were done with $n=5$ replicates. ${ }^{*} p<0.05$.

\subsection{Cartilage Tissue Production is Medium-Dependent}

The cartilage produced on the RPM was analyzed employing histochemical methods (Figure 6). Using HE staining we detected a high amount of connective tissue with several isolated cells lying apart from each other (Figure 7a-c) in the spheroids grown in DMEM/F-12. This structural composition is typical for hyaline cartilage tissue. Hyaline cartilage subsequently appears as a very uniform, glossy type tissue with evenly dispersed chondrocytes in lacunae. Hematoxylin Eosin (HE) staining revealed that spheroids produced in CGM had a very cell-rich morphology (Figure 7d-f).

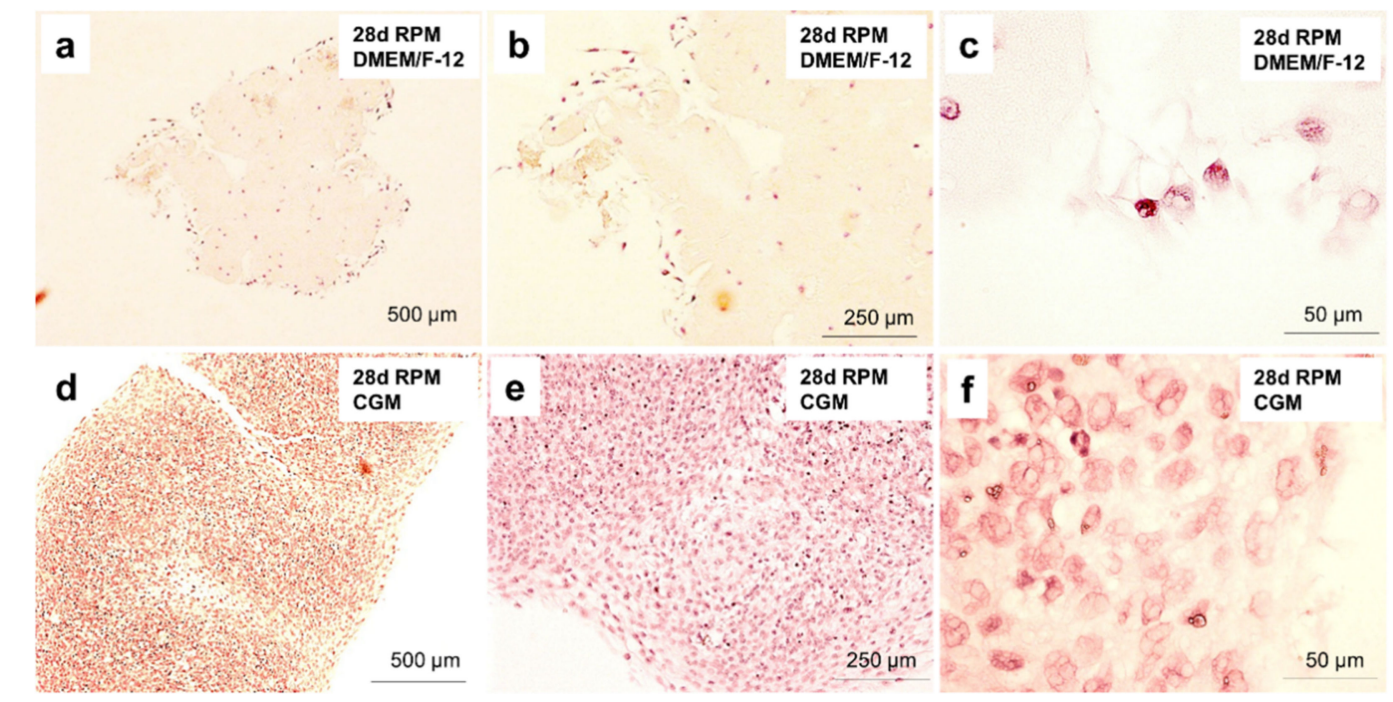

Figure 7. Histological analysis of cartilage-like tissue using Hematoxylin Eosin (HE) staining. (a) HE staining of spheroids produced on the RPM during the 28-day-cultivation in DMEM/F-12 medium. (b) Closer look at the cell content of the spheroids produced on the RPM during the 28-day-cultivation in DMEM/F-12 medium. (c) Closer look at the cell structure of the spheroids produced on the RPM during the 28-day-cultivation in DMEM/F-12 medium. (d) HE staining of spheroids produced on the RPM during the 28-day-cultivation in CGM. (e) Closer look at the cell content of the spheroids produced on the RPM during the 28-day-cultivation in CGM. (f) Closer look at the cell structure of the spheroids produced on the RPM during the 28-day-cultivation in CGM.

\subsection{Spheroids Produced on the RPM Form Monolayers under $1 \mathrm{~g}$ Culture Conditions}

After transferring them into a fresh cell culture flask, the spheroids produced on the RPM after $28 \mathrm{~d}$ of sustained cultivation were floating on the surface of the cultivation medium for the first five days (Figure 8a,d). After that time, they sedimented and re-attached to the bottom of the cell culture flask. In addition, we detected several cells which began to spread out from the main cell mass (Figure 8b,e).

After 14 days, the cultivation flask was completely confluent (Figure 8c,f). These effects were independent of the type of culture medium and occurred at the same time and rate in both DMEM/F12 and CGM medium. 


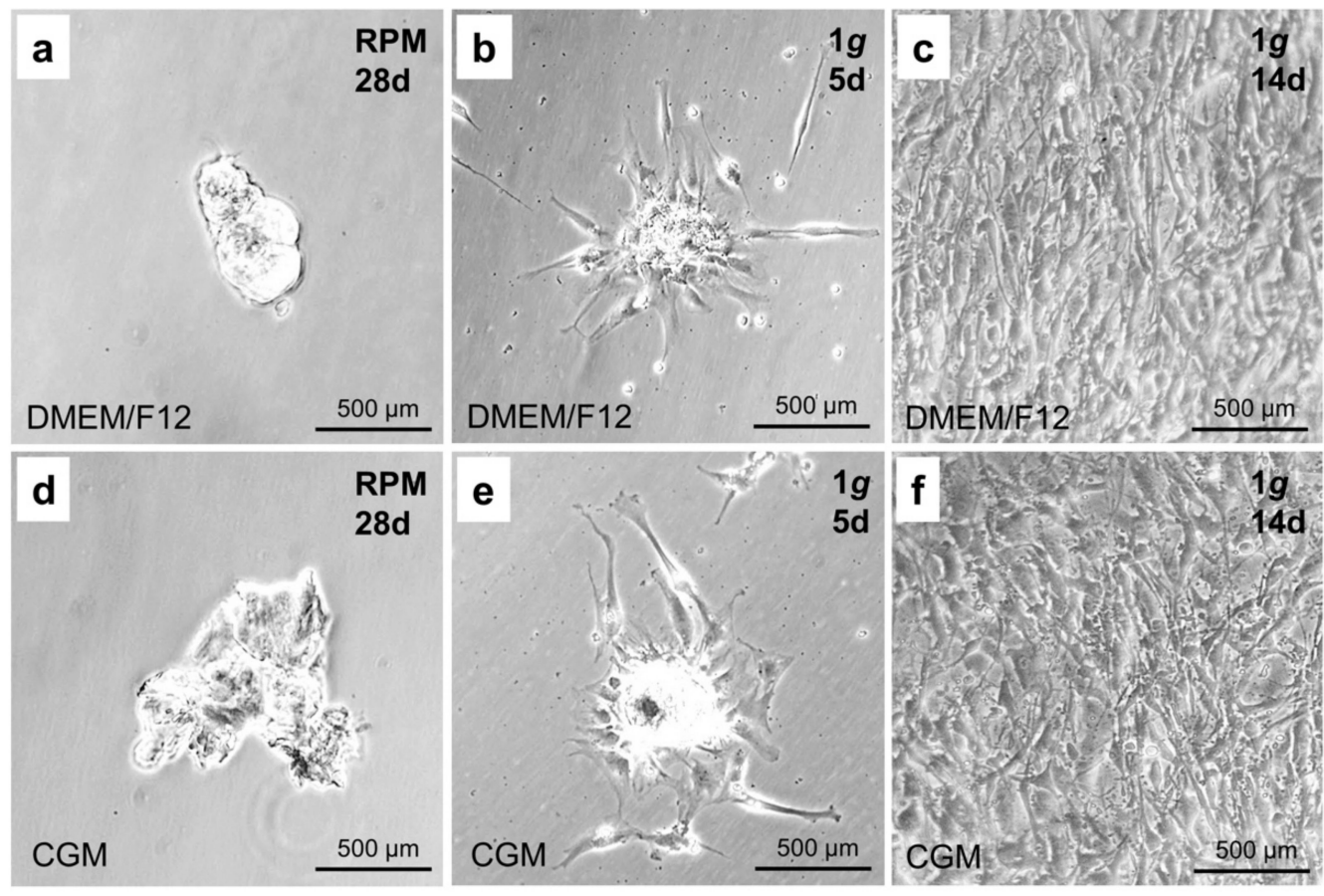

Figure 8. Spheroids produced during 28-day-cultivation on the RPM and re-cultivated under normal gravity conditions. (a) Microscopic analysis of spheroids produced after 28 days on the RPM in DMEM/F-12 medium. (b) Microscopic analysis of the spheroids produced after 28 days on the RPM in DMEM/F-12 medium after the cultivation for 5 days under normal gravity conditions $(1 \mathrm{~g})$. (c) Microscopic analysis of the spheroids produced after 28 days on the RPM in DMEM/F-12 medium after the cultivation for 14 days under normal gravity conditions $(1 \mathrm{~g})$. (d) Microscopic analysis of spheroids produced after 28 days on the RPM in CGM. (e) Microscopic analysis of the spheroids produced after 28 days on the RPM in CGM after the cultivation for 5 days under normal gravity conditions $(1 \mathrm{~g})$. (f) Microscopic analysis of the spheroids produced after 28 days on the RPM in CGM after the cultivation for 14 days under normal gravity conditions $(1 \mathrm{~g})$.

\section{Discussion}

Articular cartilage is the main load-bearing skeletal tissue of the synovial joint. It consists of an ECM made up of water (75\%), collagen type II, proteoglycan, and chondrocytes originating from mesenchymal stem cells undergoing differentiation [38-40]. Despite the fact that chondrocytes sparsely contribute to the composition of adult articular cartilage, representing only about $1 \%$ of the cartilage volume [41,42], their declining activity during skeletal development [43] influences the formation, maturation, and aging of cartilage, which results in its degradation or in injuries which could lead to OA [44].

During spaceflights, astronauts experience a reduction of mechanical forces important for cartilage maintenance. This has a negative impact on load-bearing tissues including bone and skeletal muscle and may also affect cartilage integrity and homeostasis [45]. Single cells in vitro respond to changes in gravity, and this response might play an important role for physiological changes at the organism level during spaceflight [46]. As it is still under discussion how gravitational forces can exert their effects on the cellular level, altered gravity conditions (simulated or real) offer a unique environment to study the mechanical (gravity-dependent) response of cells [32].

It is well known that microgravity can be regarded as a tool to induce 3D-growth of human cells or even tissues changing cellular morphology, phenotype, and metabolic activity [47].

Tissue engineering of cartilage, i.e., the in vitro cultivation of cell-polymer constructs consisting of bovine articular chondrocytes on polyglycolic acid scaffolds, was investigated in an earlier study by Freed et al. [48]. Chondrocytes were grown first for 3 months on Earth and then for an additional 
4 months on either MIR or on Earth in a bioreactor yielding cartilaginous constructs, each weighing between $0.3-0.4 \mathrm{~g}$ and consisting of viable, differentiated cells that synthesized proteoglycan and type II collagen [48]. Compared with the Earth group, MIR-grown constructs were more spherical and smaller.

Interestingly, our qPCR studies after $24 \mathrm{~h}$ of exposure to the RPM indicate that the chondrocytes were under a certain degree of stress at this point and show in part increased gene expression of markers of OA and cartilage damage (Figure 9).

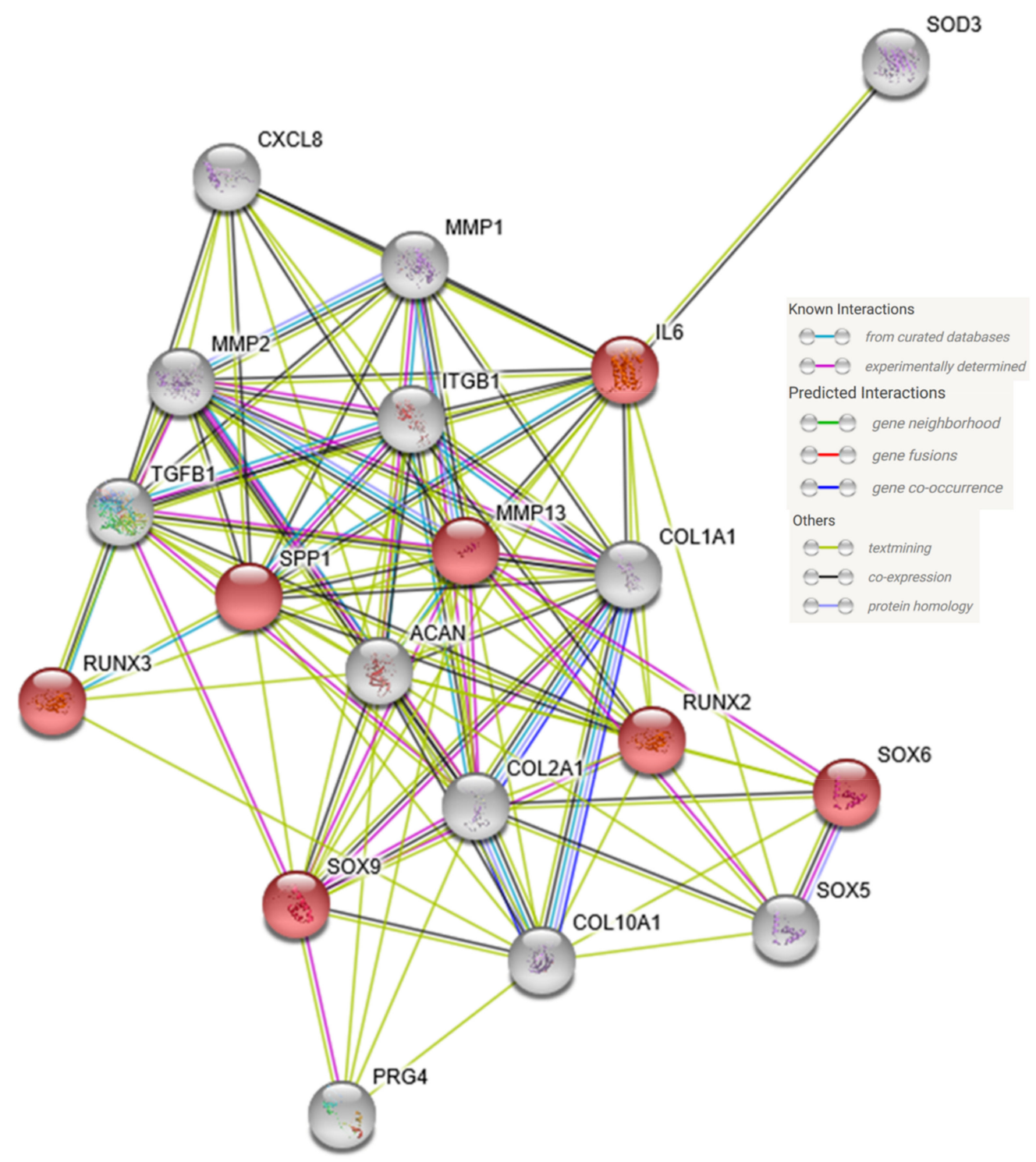

Figure 9. Mutual interaction network of the proteins encoded by the genes analyzed by quantitative real-time PCR. Colored lines represent different types of interaction as indicated in the legend. Red balls show up-regulated genes in qPCR, gray balls unregulated genes.

It has been shown that patients suffering from OA or rheumatoid arthritis had significantly higher concentrations of the pro-inflammatory cytokines IL6 and IL8 in their serum and synovial fluid than healthy subjects [49]. Furthermore, IL6 receptor blockade using tocilizumab preserved the articular cartilage in a mouse model of osteonecrosis [50]. Lastly, in accordance with our results, IL6 has been shown to stimulate MMP1, -3 , and -13 via JAK-STAT and ERK-MAPK signaling in chondrocytes [51]. While the increase in $M M P 1$ gene expression in our experiment was not significant, MMP13 expression was significantly increased by about 3-fold. Among the MMP family, MMP13 has the highest specificity for collagen type II and can also degrade aggrecan [52], thus promoting collagen 
degeneration. It is also almost exclusively expressed in chondrocytes, making MMP13 an interesting target for OA therapy [52].

Of note, osteopontin has also been found to be a regulator of MMP13 expression. While the majority of studies indicated that elevated osteopontin expression is associated with increased cartilage degeneration [53-56], suggesting that it is an inducer of MMP13 expression, there are some contrary findings [57]. However, our data supports the inducer-model, as we also found concomitantly increased SPP1 and MMP13 gene expression levels after $24 \mathrm{~h}$ on the RPM.

Beside those genes indicative of cartilage damage, we also observed the overexpression of genes involved in cartilage development, maintenance, and differentiation. The most central transcription factor is SOX9. It directly targets genes of important cartilage-specific extracellular matrix molecules (collagen type II, IX, XI aggrecan and link protein), their regulators such as chondroitin 4-sulfotransferase, related transcription factors such as SOX5 and -6 or RUNX2 and -3, and important cartilage signaling pathway mediators (fibroblast growth factor receptor-3) [58-63]. SOX9 and SOX5/6 constitute a trio which is sufficient for chondrogenesis. It binds to so-called super enhancers clustered throughout the genome to which the cartilage-specific genes are linked [62]. In addition, SOX9 shows non-transcriptional activities, most notably by interacting with RUNX2, acting as a repressor [64]. SOX9 knockdown caused apoptosis in round chondrocytes and terminal maturation with strong apoptosis in flat chondrocytes. It was therefore concluded that SOX9 expression is associated with chondrocyte survival [65].

On the other hand, RUNX2 and 3 are usually only weakly expressed in resting and proliferating chondrocytes but up-regulated in pre-hypertrophic, hypertrophic, and terminally hypertrophic chondrocytes, driving chondrocyte maturation and endochondral ossification [66-68]. In terminal hypertrophic chondrocytes, RUNX2 regulates the expression of SPP1 and MMP13, among others [69-72]. This and the findings that Run $x 2^{+/-}$mice were resistant to OA [73] and that a RUNX2 deletion resulted in an attenuation of the progression of OA in a surgically induced mouse model [74] indicate that RUNX2 plays a central role in the pathogenesis of OA.

Summarizing our qPCR findings, after $24 \mathrm{~h}$ on the RPM the chondrocytes were proliferating well, as indicated by their SOX6/9 gene expression profiles. However, they also had undergone some microgravity-induced changes, which might be the first steps toward hypertrophy, matrix degeneration, and ossification. After a prolonged exposure to the RPM, however, these processes did not progress, but we found cartilage-like tissue constructs without signs of chondrocyte maturation or matrix depletion. We therefore propose that the chondrocytes, after the initial shock of simulated microgravity growth conditions, were able to adapt to cultivation on the RPM and suppress most of the deleterious processes.

The Rotating Wall Vessel (RWV) developed by NASA proved to be a useful tool for providing an environment that enabled dedifferentiated chondrocytes to re-differentiate and produce a cartilage-specific extracellular matrix. Dedifferentiated chondrocytes exposed to the RWV for 12 weeks also showed spontaneous aggregation and formation of solid tissue [75]. However, we had demonstrated earlier that human chondrocytes when exposed to the RPM start forming 3D cell assemblies within five days [18]. In this study, we also showed that initially after a 24-h RPM exposure, the cells revealed no signs of apoptosis [18]. The adherent cell layer on the RPM served as a starting point for the transition from monolayer cells to 3D spheroids which takes about 5-7 days [76]. Aleshcheva et al. reported the small 3D spheroids engineered on the RPM [76]. Moreover, the RPM-derived cartilage production has never been accelerated and the produced tissue has never been implemented into an animal model, which should be done in the future. According to our results, chondrocytes are able to produce cartilage tissue on the RPM already after 28 days of cultivation using DMEM/F-12 medium, demonstrating a strong positive staining with monoclonal antibodies against collagen type II and articular proteoglycan. Using chondrocyte-specific medium (CGM) it was possible to achieve comparable results after only 14 days.

Another approach for cartilage tissue engineering is the use of mesenchymal stem cells (MSC) derived either from bone marrow or from adipose tissue [77]. In general, simulated microgravity 
seemed to be beneficial in promoting the differentiation of MSC into a chondrogenic phenotype. Ohyabu and team demonstrated large tissues with a cartilaginous differentiation after exposing rabbit MSCs to an RWV for 4 weeks [78]. Similar results were reported by other authors, who demonstrated that growing MSCs under conditions of s- $\mu \mathrm{g}$ results in a better quality of the cartilage specimen in comparison to standard $1 g$ spheroid culture techniques [79-81]. Furthermore, Yuge et al. showed that hMSC s exposed to 3D clinorotation were characterized by a strong proliferative potential and were able to differentiate into hyaline cartilage after transplantation [80]. It has to be mentioned that there are also controversial reports. Mayer-Wagner et al. used the RWV bioreactor and found a reduced chondrogenic potential of hMSCs during chondrogenic differentiation. Moreover, COL2A1 was likewise reduced and the COL2A1/COL10A1 ratio decreased under RWV conditions [82]. These data show that future studies are necessary to find the best method or device suitable for tissue engineering of cartilage. The RPM has proven to be suitable for tissue engineering purposes of various tissues such as vascular constructs and bone tissues [83-85]. Similar tubular constructs to those engineered on the RPM have been observed in space during the ESA-SPHEROIDS space mission $[84,86]$.

In summary, a long-term RPM exposure of chondrocytes was suitable to engineer cartilaginous tissues expressing cartilage markers. With respect to cartilage regeneration approaches, our findings indicate that scaffold-free RPM-derived chondrocyte spheroids retain the ability to attach to surfaces and to spread out onto it, firmly anchoring the tissue construct to its new environment. We suggest that this characteristic will allow for an OA therapy in the future.

\section{Materials and Methods}

\subsection{Cells and Culture Medium}

Commercially available human chondrocytes (Provitro ${ }^{\circledR}$, Berlin, Germany) were cultured in DMEM/F-12 medium (ThermoFisher Scientific, Waltham, Massachusetts, United States) and Chondrocyte Growth Medium (CGM; Provitro ${ }^{\circledR}$, Berlin, Germany), both supplemented with $10 \%$ fetal calf serum (Biochrom ${ }^{\circledR}$, Berlin, Germany) and antibiotics (100 IU penicillin/mL and $100 \mu \mathrm{g}$ streptomycin/mL, Biochrom ${ }^{\circledR}$, Berlin, Germany)

The cells from frozen stocks (passage 1) were grown in T175 cell culture flasks $\left(175 \mathrm{~cm}^{2}\right.$; Sarstedt, Nümbrecht, Germany) until sub-confluent layers (70-80\%) were obtained. Afterwards, the cells were subcultured (passage 2) in 5 T175 cell culture flasks. After reaching $70 \%$ confluence, cells from 3 T175 (passage 3) were combined and $10^{6}$ cells were seeded into each of $30 \mathrm{~T} 25$ cell culture flasks $\left(25 \mathrm{~cm}^{2}\right.$; Sarstedt, Nümbrecht, Germany) for the RPM experiments ( $n=15$ for the RPM and $n=15$ as $1 \mathrm{~g}$ control samples).

\subsection{Random Positioning Machine}

Altered gravity conditions were simulated using a desktop RPM, manufactured by Airbus Defense and Space Netherlands (formerly Dutch Space, Leiden, The Netherlands). The RPM is an instrument that can rotate a (biological) sample around all three axes in space, resulting in randomization of the influence of gravity. Whether this situation is experienced by the exposed systems such as "microgravity" has to be validated by space experiments and thus real microgravity conditions $[87,88]$. The RPM consists of two frames, which can be rotated independently, and are controlled by a dedicated software. To minimize residual acceleration, the samples were mounted as near to the center of rotation as possible and air bubbles avoided. Thirty T25 culture flasks containing confluent chondrocyte monolayers were completely filled with medium. Fifteen of these flasks were fixed on the RPM, which was then operated at an average angular velocity of $60^{\circ} / \mathrm{s}$ using the real random mode, varying both the speed and the movement direction of the frames. The RPM was positioned in a commercially available incubator at $37^{\circ} \mathrm{C}$ and $5 \% \mathrm{CO}_{2}$. Fifteen T25 culture flasks used for $1 \mathrm{~g}$ static ground control cultures were filled in parallel and placed in the same incubator as the RPM. Media were exchanged every $48 \mathrm{~h}$. 
After 7, 14, 21, and 28 days, three T25 flasks were removed from both the RPM and the control group, and adherent cells (RPM and controls) and spheroids (RPM) were collected for further investigations.

\subsection{Histological Analysis}

Following the RPM run, the spheroids were carefully removed from the medium after 7, 14, 21 and $28 \mathrm{~d}$ of cultivation, fixed in $4 \%$ paraformaldehyde (PFA; Sigma, Taufkirchen, Germany), embedded in paraffin, and sectioned into $3 \mu \mathrm{m}$ thick slices. One slice from each group was stained with hematoxylin and eosin (Sigma, Taufkirchen, Germany) to gain an overview of the tissue structure and cell distribution.

\subsection{Immunohistochemical Analyses}

For immunohistochemistry, sections were deparaffinized according to standard procedures and stained with antibodies against human collagen type I, collagen type II, and aggrecan.

Briefly, slides were blocked for endogenous peroxidase activity with $2 \%$ hydrogen peroxide in DPBS for 15-20 min at room temperature. Then they were treated with pepsin $(1 \mathrm{mg} / \mathrm{mL}$; Sigma, Taufkirchen, Germany) in $0.5 \mathrm{M}$ acetic acid for collagen types I and collagen II ( $30 \mathrm{~min}$ at $37^{\circ} \mathrm{C}$ ) and with chondroitinase $\mathrm{ABC}(0.2 \mathrm{U} / \mathrm{mL}$; Boehringer Mannheim Biochemica, Mannheim, Germany) in $0.1 \mathrm{M}$ Tris-acetate buffer at $\mathrm{pH} 8.0$ for cartilage proteoglycan $\left(2 \mathrm{~h}\right.$ at $\left.37^{\circ} \mathrm{C}\right)$. The sections were rinsed with PBS and incubated for $30 \mathrm{~min}$ at $25^{\circ} \mathrm{C}$ with normal goat serum diluted 1:10 in PBS. Primary antibodies were diluted in PBS-2\% bovine serum albumin (BSA; Sigma) as follows: anti-collagen type I 1:100, anti-collagen type II 1:100, and anti-human aggrecan 1:50. The antibody solutions were then incubated with the sections in a humidified chamber for $1 \mathrm{~h}$ at room temperature. After incubation, the slides were washed three times with PBS and incubated for $1 \mathrm{~h}$ with biotin-conjugated goat anti-mouse secondary antibody (Vector Laboratories, Burlingame, CA, USA) diluted 1:100 in PBS/2\% BSA. The slides were then treated with avidin-biotin (Vectastain ABC kit; Vector Laboratories) for $30 \mathrm{~min}$ and incubated with diaminobenzidine (DAB) substrate solution (Sigma) for approximately 10-15 min until the brown color developed. Then they were rinsed with PBS, counterstained with hematoxylin, rinsed with water, dehydrated, and finally sealed using Eukitt (Kindler, Freiburg, Germany).

All experiments included negative controls, which were treated with DPBS only, to test for unspecific binding by the secondary antibody.

\subsection{Immunofluorescence Staining}

For immunofluorescence staining, the cells $\left(10^{6} \mathrm{cells} / \mathrm{cm}^{2}\right)$ were seeded into several four-chamber Super Cell chamber slides (BD, Heidelberg, Germany) and placed in the incubator $\left(37^{\circ} \mathrm{C}, 5 \% \mathrm{CO}_{2}\right)$ overnight until they attached to the slides. The next day, the slides were completely filled with medium, sealed with parafilm, and placed on the RPM for the run. After the run, the chondrocytes were washed twice with DPBS, fixed for $30 \mathrm{~min}$ with $4 \%$ paraformaldehyde at $4{ }^{\circ} \mathrm{C}$, and permeabilized with Triton X-100 (Sigma, Taufkirchen, Germany). The cells were then washed twice in DPBS and incubated with primary antibody for $24 \mathrm{~h}$ at room temperature. The morphology of the microtubules and intermediate filaments were determined by indirect immunofluorescence (IIF). After incubation with the primary antibody (beta-tubulin, 1:1000, vimentin, 1:1000; both Cell Signaling Technology, Inc., Danvers, MA, USA), the chondrocytes were washed twice with DPBS and incubated for $2 \mathrm{~h}$ with the secondary FITC-tagged antibody, used at a dilution of 1:500 (Cell Signaling Technology, Inc., Danvers, MA, USA). For nuclear staining, we used Hoechst dye 33342 (Molecular Probes, Eugene, OR, USA) for 5 min and washed the cells twice with DPBS. The cells were mounted with Vectashield ${ }^{\circledR}$ immunofluorescence mounting medium (Vector, Burlingame, CA, USA), and analyzed microscopically.

\subsection{F-Actin Staining}

F-actin was visualized by means of rhodamine-phalloidin staining (Molecular Probes ${ }^{\circledR}$, Eugene, OR, USA) [19,89]. For this, adherent cells were fixed for 30 min with $4 \%$ PFA (in DPBS), washed twice 
with DPBS, incubated with $5 \mu \mathrm{g} / \mathrm{mL}$ fluorescent phalloidin conjugate solution in PBS/1\% BSA for at least $20 \mathrm{~min}$ at room temperature, and then washed several times with PBS to remove unbound phalloidin conjugate. Afterwards, the nuclei were stained with Hoechst 33342 (Molecular Probes ${ }^{\circledR}$, Eugene, OR, USA) for $5 \mathrm{~min}$ and washed twice with DPBS. For evaluation, the samples were mounted with Vectashield ${ }^{\circledR}$ (Vector, Burlingame, CA, USA) and analyzed microscopically.

\subsection{Microscopy}

The viability and morphology of the cells grown on four-chamber Super Cell slides (BD, Heidelberg, Germany) were examined by phase contrast microscopy (Olympus, Hamburg, Germany) immediately after RPM exposure. Immunofluorescence and F-actin staining were analyzed with a Zeiss 510 META inverted confocal laser scanning microscope (Zeiss, Germany) equipped with a Plan-Apochromat $63 \times 1.4$ objective. Excitation and emission wavelengths were as follows: $\lambda_{\mathrm{exc}}=488 \mathrm{~nm}$ and $\lambda_{\mathrm{em}}=505 \mathrm{~nm}$ for FITC. All samples were analyzed with the help of the image analysis program Scion Image (Version 1.63 MacOs, Scion Corporation, Chicago, IL, USA).

\subsection{Transmission Electron Microscopy (TEM)}

Following the RPM run, the spheroids derived from passage 3 chondrocytes were fished from the medium after $7 \mathrm{~d}, 14 \mathrm{~d}, 21 \mathrm{~d}$ and $28 \mathrm{~d}$ cultivation and fixed in Karnovsky fixative. The samples were then embedded in EMbed-812 resin blocks using a LYNX EI tissue processor (Leica Biosystems, Nussloch, Germany). After a first assessment of semi-thin sections $(0.8 \mu \mathrm{m}$, toluidine blue/fuchsin double staining) by light microscopy, representative blocks were chosen for further ultra-thin sectioning (80 nm). Contrasting was done with $\mathrm{Pb}$-citrate and U-acetate. TEM analyses were performed with a LEO912AB (Zeiss, Oberkochen, Germany) instrument, equipped with a $2 \mathrm{k} \times 2 \mathrm{k}$ pixel side-entry CCD-camera (TRS, Moorenweis, Germany) and the iTEM image analysis software (OSIS, Münster, Germany).

\subsection{RNA Isolation}

Ten cell culture flasks from each time point were used for RNA extraction. The cells were scraped off using cell scrapers (Sarstedt, Nümbrecht, Germany), transferred to $50 \mathrm{~mL}$ tubes, and pelleted by centrifugation $\left(2500 \mathrm{~g}, 10 \mathrm{~min}, 4^{\circ} \mathrm{C}\right.$ ). The RNeasy Mini Kit (Qiagen, Hilden, Germany) was used according to the manufacturer's instructions to isolate total RNA. RNA concentrations and quality were determined spectrophotometrically at $260 \mathrm{~nm}$ using a NanoDrop instrument (Thermo Scientific, Wilmington, DE, USA). The isolated RNA had an A260/280 ratio of 1.5 or higher. cDNA designated for quantitative real-time PCR was then obtained using the First-Strand cDNA Synthesis Kit (Fermentas, St. Leon-Rot, Germany) using $1 \mu \mathrm{g}$ of total RNA in a $20-\mu \mathrm{L}$ reaction mixture at room temperature.

\subsection{Quantitative Real-Time PCR}

Quantitative real-time PCR [90-92] was used to determine the expression levels of selected genes after $24 \mathrm{~h}$ or $7 \mathrm{~d}, 14 \mathrm{~d}, 21 \mathrm{~d}$, and $28 \mathrm{~d}$ incubation under simulated microgravity ( $\mu$ g) compared to the static control group $(1 \mathrm{~g})$. Primer Express ${ }^{\circledR}$ software (Applied Biosystems, Darmstadt, Germany) was employed to design all primers with a $\mathrm{T}_{\mathrm{m}}$ of about $60^{\circ} \mathrm{C}$. The primers were synthesized by TIB Molbiol (Berlin, Germany) and are given in Table 1. All assays were run on an Applied Biosystems 7500 Fast Real-Time PCR System using the Fast SYBR ${ }^{\circledR}$ Green PCR Master Mix (both Applied Biosystems, Darmstadt, Germany). The reaction volume was $25 \mu \mathrm{L}$ including $1 \mu \mathrm{L}$ of template cDNA and a final random hexamer primer concentration of $500 \mathrm{nM}$. PCR conditions were as follows: $20 \mathrm{~s}$ at $95{ }^{\circ} \mathrm{C}$, 40 cycles of $3 \mathrm{~s}$ at $95^{\circ} \mathrm{C}$, and $30 \mathrm{~s}$ at $60^{\circ} \mathrm{C}$, followed by a melting curve analysis step (temperature gradient from 60 to $95^{\circ} \mathrm{C}$ with $+0.3^{\circ} \mathrm{C} /$ cycle). 
Table 1. List of primers used for qPCR analyses.

\begin{tabular}{|c|c|c|}
\hline Gene & Forward Primer & Reverse Primer \\
\hline $18 S$ rRNA & GGAGCCTGCGGCTTAATTT & CAACTAAGAACGGCCATGCA \\
\hline$A C A N$ & AGTCCAACTCTTCAAGGTGAACTA & ACTCAGCGAGTTGTCATGGT \\
\hline COL1A1 & ACGAAGACATCCCACCAATCAC & CGTTGTCGCAGACGCAGAT \\
\hline COL2A1 & GGCAATAGCAGGTTCACGTACA & CGATAACAGTCTTGCCCCACTT \\
\hline COL10A1 & GGGCAGAGGAAGCTTCAGAAA & TCTCAGATGGATTCTGCGTGC \\
\hline IL6 & CGGGAACGAAAGAGAAGCTCTA & GAGCAGCCCCAGGGAGAA \\
\hline CXCL8 & TGGCAGCCTTCCTGATTTCT & GGGTGGAAAGGTTTGGAGTATG \\
\hline ITGB1 & GAAAACAGCGCATATCTGGAAATT & CAGCCAATCAGTGATCCACAA \\
\hline$M M P 1$ & GTCAGGGGAGATCATCGGG & GAGCATCСССТССАATACСТG \\
\hline MMP2 & CCATGATGGAGAGGCAGACA & CCATGATGGAGAGGCAGACA \\
\hline MMP13 & AGCCTTCAAAGTTTGGTCCGA & TCGCCATGCTCCTTAATTCCA \\
\hline PRG4 & CССССАAACCACCAGTTGTA & ACGTGTCAGGAGTTGTGACC \\
\hline RUNX2 & GAACCCAGAAGGCACAGACA & GGATGAGGAATGCGCCCTAA \\
\hline RUNX3 & GTGGGCGAGGGAAGAGTTTC & CCTTGATGGCTCGGTGGTAG \\
\hline SOD3 & CTGGAAAGGTGCCCGACTCC & ATGTCTCGGATCCACTCCGC \\
\hline SOX5 & TCCTCССTCCAGGCTTCAG & CTGCCATGGTAGTTGGGATCA \\
\hline SOX6 & GCCACACATTAAGCG & TCCAGCGAGATCCTAAGATTTTG \\
\hline SOX9 & AGGAAGTCGGTGAAGAACGG & CGCCTTGAAGATGGCGTTG \\
\hline SPP1 & CGAGGTGATAGTGTGGTTTATGGA & CGTCTGTAGCATCAGGGTACTG \\
\hline TGFB1 & CACCCGCGTGCTAATGGT & AGAGCAACACGGGTTCAGGTA \\
\hline
\end{tabular}

If all amplicons showed a single $\mathrm{T}_{\mathrm{m}}$ similar to the one predicted by the Primer Express ${ }^{\circledR}$ software; the PCR reactions were considered specific. Every sample was measured in triplicate. The comparative $\mathrm{C}_{\mathrm{T}}\left(\Delta \Delta \mathrm{C}_{\mathrm{T}}\right)$ method was used for the relative quantification of transcription levels. 18S rRNA was used as a housekeeping transcript to normalize expression data.

\subsection{STRING-Analysis}

To generate the interaction network of genes analyzed by qPCR, we used the STRING V11.0 tool [93] (available at https://string-db.org/).

\subsection{Statistical Analysis}

All statistical analyses were performed using IBM SPSS Statistics 24.0 (IBM, Armonk, NY, USA). We tested all parameters achieved by qPCR analyses using one-way ANOVA or the Mann-Whitney $\mathrm{U}$ test (depending on the results of a normality test). All data are expressed as means \pm standard deviation (SD). Differences were considered significant at $p<0.05$.

\section{Conclusions}

Exposure of human chondrocytes to the RPM and thus a new environment by random positioning increased the current knowledge about tissue engineering of cartilage. We could demonstrate that the cultivation medium has a direct impact on the speed of 3D formation and tissue composition. The 3D tissues revealed cartilaginous characteristics that make them potential candidates for cellular cartilage regeneration approaches in OA therapy. Moreover, the results initiated by gravitational biomedical research provide a new technology to support the development of patient-specific therapies and a challenge for future applications in translational regenerative medicine.

Author Contributions: Conceptualization, D.G. and M.W.; methodology, G.A., S.K., P.S., and J.S.; software, M.W.; validation, D.G., S.K., and M.W.; formal analysis, M.W., G.A., D.G., and J.S.; investigation, G.A. and J.S.; resources, R.H., M.I., and D.G.; writing—original draft preparation, D.G., M.W., and G.A.; writing—review and editing, D.G., R.H., R.L., and M.W.; visualization, M.W. and G.A.; supervision, D.G. and R.H.; project administration, D.G.; funding acquisition, D.G. and M.I. All authors have read and agreed to the published version of the manuscript. 
Funding: This research was funded by the German Space Agency (DLR; (DG) BMWi project 50WB1924) and the European Space Agency (ESA; CORA-GBF-2013-004).

Acknowledgments: The authors would like to thank the Helmholtz Space Life Sciences Research School (SpaceLife), Aarhus University, Denmark, and DGLRM (Young Fellow Program for GA). The authors are grateful to Josef Schröder (EM core facility, Institute for Pathology, University Clinic Regensburg, Germany) for his expertise in TEM analysis.

Conflicts of Interest: The authors declare no conflict of interest

\section{Abbreviations}

$\begin{array}{ll}\mu g & \text { Microgravity } \\ \text { ACAN } & \text { Aggrecan } \\ \text { bFGF } & \text { Basic fibroblast growth factor } \\ \text { CGM } & \text { Chondrocyte growth medium } \\ \text { COL10A1 } & \text { Collagen alpha-1(X) chain } \\ \text { COL1A1 } & \text { Collagen, type I, alpha 1, } \\ \text { COL2A1 } & \text { Collagen, type II, alpha 1 } \\ \text { DMEM } & \text { Dulbecco's Modified Eagle Medium } \\ \text { ECM } & \text { Extracellular matrix } \\ \text { EGF } & \text { Epidermal growth factor } \\ \text { ERK } & \text { Extracellular signal-regulated kinase } \\ \text { FCS } & \text { Fetal calf serum } \\ \text { IL6 } & \text { Interleukin 6 } \\ \text { IL8 } & \text { Interleukin 8 } \\ \text { ITGB1 } & \text { Integrin beta-1 } \\ \text { JAK } & \text { Janus kinase } \\ \text { MAPK } & \text { Mitogen-activated protein kinase } \\ \text { MMP1 } & \text { Matrix metalloproteinase-1 } \\ \text { MMP2 } & \text { Matrix metalloproteinase-2 } \\ \text { MMP13 } & \text { Matrix metalloproteinase-13 } \\ \text { PFA } & \text { Paraformaldehyde } \\ \text { OA } & \text { Ostheoarthritis } \\ \text { PRG4 } & \text { Proteoglycan 4 } \\ \text { qPCR } & \text { Quantitative real-time PCR } \\ \text { R3 IGF-1 } & \text { R3 insulin-like growth factor-1 } \\ \text { RPM } & \text { Random Positioning Machine } \\ \text { RUNX2 } & \text { Runt-related transcription factor 2 } \\ \text { RUNX3 } & \text { Runt-related transcription factor 3 } \\ \text { RWV } & \text { Rotating Wall Vessel } \\ \text { SOD3 } & \text { Extracellular superoxide dismutase } \\ \text { SOX5 } & \text { SRY-related HMG-box transcription factor 5 } \\ \text { SOX6 } & \text { SRY-related HMG-box transcription factor 6 } \\ \text { SOX9 } & \text { SRY-related HMG-box transcription factor 9 } \\ \text { SPP1 } & \text { Osteopontin } \\ \text { STAT } & \text { Signal transducer and activator of transcription } \\ \text { TEM } & \text { Transmission electron microscopy } \\ \text { TGFB1 } & \text { Transforming growth factor beta 1 } \\ \text { VEGF } & \text { Vascular endothelial growth factor } \\ & \end{array}$

\section{References}

1. Chang, C.-H.; Lin, F.-H.; Kuo, T.-F.; Liu, H.-C. Cartilage Tissue Engineering. Biomed. Eng. Appl. Basis Commun. 2005, 17, 61-71. [CrossRef]

2. Mehrotra, C.; Remington, P.L.; Naimi, T.S.; Washington, W.; Miller, R. Trends in total knee replacement surgeries and implications for public health, 1990-2000. Public Health Rep. 2005, 120, 278-282. [CrossRef] 
3. Kock, L.; van Donkelaar, C.C.; Ito, K. Tissue engineering of functional articular cartilage: The current status. Cell Tissue Res. 2012, 347, 613-627. [CrossRef]

4. Uemura, T.; Nishi, M.; Aoki, K.; Tsumura, T. Cartilage Regeneration from Bone Marrow Cells Using RWV Bioreactor and Its Automation System for Clinical Application. In Tissue Engineering for Tissue and Organ Regeneration; Eberli, D., Ed.; IntechOpen: Rijeka, Croatia, 2011.

5. Wenger, R.; Hans, M.G.; Welter, J.F.; Solchaga, L.A.; Sheu, Y.R.; Malemud, C.J. Hydrostatic pressure increases apoptosis in cartilage-constructs produced from human osteoarthritic chondrocytes. Front. Biosci. 2006, 11, 1690-1695. [CrossRef]

6. Marlovits, S.; Tichy, B.; Truppe, M.; Gruber, D.; Vecsei, V. Chondrogenesis of aged human articular cartilage in a scaffold-free bioreactor. Tissue Eng. 2003, 9, 1215-1226. [CrossRef]

7. Giannoni, P.; Pagano, A.; Maggi, E.; Arbico, R.; Randazzo, N.; Grandizio, M.; Cancedda, R.; Dozin, B. Autologous chondrocyte implantation (ACI) for aged patients: Development of the proper cell expansion conditions for possible therapeutic applications. Osteoarthr. Cartil. 2005, 13, 589-600. [CrossRef]

8. Foldager, C.B.; Nielsen, A.B.; Munir, S.; Ulrich-Vinther, M.; Soballe, K.; Bunger, C.; Lind, M. Combined 3D and hypoxic culture improves cartilage-specific gene expression in human chondrocytes. Acta Orthopeadica 2011, 82, 234-240. [CrossRef]

9. Barbero, A.; Grogan, S.; Schafer, D.; Heberer, M.; Mainil-Varlet, P.; Martin, I. Age related changes in human articular chondrocyte yield, proliferation and post-expansion chondrogenic capacity. Osteoarthr. Cartil. 2004, 12, 476-484. [CrossRef]

10. Kim, I.L.; Mauck, R.L.; Burdick, J.A. Hydrogel design for cartilage tissue engineering: A case study with hyaluronic acid. Biomaterials 2011, 32, 8771-8782. [CrossRef]

11. Darling, E.M.; Athanasiou, K.A. Rapid phenotypic changes in passaged articular chondrocyte subpopulations. J. Orthop. Res. 2005, 23, 425-432. [CrossRef]

12. Saltzman, W.M. Weaving cartilage at zero g: The reality of tissue engineering in space. Proc. Natl. Acad. Sci. USA 1997, 94, 13380-13382. [CrossRef]

13. Stamenkovic, V.; Keller, G.; Nesic, D.; Cogoli, A.; Grogan, S.P. Neocartilage formation in 1 g, simulated, and microgravity environments: Implications for tissue engineering. Tissue Eng. Part A 2010, 16, 1729-1736. [CrossRef]

14. Borst, A.G.; van Loon, J.J.W.A. Technology and Developments for the Random Positioning Machine, RPM. Microgravity Sci. Technol. 2008, 21, 287. [CrossRef]

15. Kruger, M.; Melnik, D.; Kopp, S.; Buken, C.; Sahana, J.; Bauer, J.; Wehland, M.; Hemmersbach, R.; Corydon, T.J.; Infanger, M.; et al. Fighting Thyroid Cancer with Microgravity Research. Int. J. Mol. Sci. 2019, 20, 2553. [CrossRef]

16. Kopp, S.; Warnke, E.; Wehland, M.; Aleshcheva, G.; Magnusson, N.E.; Hemmersbach, R.; Corydon, T.J.; Bauer, J.; Infanger, M.; Grimm, D. Mechanisms of three-dimensional growth of thyroid cells during long-term simulated microgravity. Sci. Rep. 2015, 5, 16691. [CrossRef]

17. Kopp, S.; Slumstrup, L.; Corydon, T.J.; Sahana, J.; Aleshcheva, G.; Islam, T.; Magnusson, N.E.; Wehland, M.; Bauer, J.; Infanger, M.; et al. Identifications of novel mechanisms in breast cancer cells involving duct-like multicellular spheroid formation after exposure to the Random Positioning Machine. Sci. Rep. 2016, 6, 26887. [CrossRef]

18. Ulbrich, C.; Westphal, K.; Pietsch, J.; Winkler, H.D.; Leder, A.; Bauer, J.; Kossmehl, P.; Grosse, J.; Schoenberger, J.; Infanger, M.; et al. Characterization of human chondrocytes exposed to simulated microgravity. Cell. Physiol. Biochem. 2010, 25, 551-560. [CrossRef]

19. Grimm, D.; Infanger, M.; Westphal, K.; Ulbrich, C.; Pietsch, J.; Kossmehl, P.; Vadrucci, S.; Baatout, S.; Flick, B.; Paul, M.; et al. A delayed type of three-dimensional growth of human endothelial cells under simulated weightlessness. Tissue Eng. Part A 2009, 15, 2267-2275. [CrossRef]

20. Stockwell, R.A.; Meachim, G. The chondrocytes. In Adult Articular Cartilage; Freeman, M.A.R., Ed.; Pitman Medical: London, UK, 1973; pp. 51-99.

21. Dingle, J.T. The secretion of enzymes into the pericellular environment. Philos. Trans. R. Soc. Lond. B Biol. Sci. 1975, 271, 315-324.

22. Stockwell, R.A. Chondrocytes. Suppl. (R. Coll. Pathol.) 1978, 12, 7-13. [CrossRef]

23. Meachim, G.; Roy, S. Intracytoplasmic filaments in the cells of adult human articular cartilage. Ann. Rheum. Dis. 1967, 26, 50-58. [CrossRef] 
24. Ishikawa, H.; Bischoff, R.; Holtzer, H. Formation of arrowhead complexes with heavy meromyosin in a variety of cell types. J. Cell Biol. 1969, 43, 312-328. [CrossRef]

25. Bush, P.G.; Hoemann, C.D.; Hall, A.C. A Similarity between Morphology of Chondrocytes within Degenerate Cartilage and Those Cultured in a Weak 3D Matrix. In Proceedings of the 47th Annual Meeting of the Orthopaedic Research Society, San Francisco, CA, USA, 25-28 February 2001; Volume 26, p. 0661.

26. Canty, E.G.; Kadler, K.E. Procollagen trafficking, processing and fibrillogenesis. J. Cell Sci. 2005, 118 Pt 7, 1341-1353. [CrossRef]

27. Turner, C.E.; Burridge, K. Transmembrane molecular assemblies in cell-extracellular matrix interactions. Curr. Opin. Cell Biol. 1991, 3, 849-853. [CrossRef]

28. Sims, J.R.; Karp, S.; Ingber, D.E. Altering the cellular mechanical force balance results in integrated changes in cell, cytoskeletal and nuclear shape. J. Cell Sci. 1992, 103 Pt 4, 1215-1222.

29. Juliano, R.L.; Haskill, S. Signal transduction from the extracellular matrix. J. Cell Biol. 1993, 120, 577-585. [CrossRef]

30. Simon, V.R.; Pon, L.A. Actin-based organelle movement. Experientia 1996, 52, 1117-1122. [CrossRef]

31. Riezman, H.; Munn, A.; Geli, M.I.; Hicke, L. Actin-, myosin- and ubiquitin-dependent endocytosis. Experientia 1996, 52, 1033-1041. [CrossRef]

32. Vorselen, D.; Roos, W.H.; MacKintosh, F.C.; Wuite, G.J.; van Loon, J.J. The role of the cytoskeleton in sensing changes in gravity by nonspecialized cells. FASEB J. 2014, 28, 536-547. [CrossRef]

33. Vale, R.D. Intracellular transport using microtubule-based motors. Annu. Rev. Cell Biol. 1987, 3, 347-378. [CrossRef]

34. Mitchison, T.; Evans, L.; Schulze, E.; Kirschner, M. Sites of microtubule assembly and disassembly in the mitotic spindle. Cell 1986, 45, 515-527. [CrossRef]

35. Gibbons, I.R. Cilia and flagella of eukaryotes. J. Cell Biol. 1981, 91 Pt 2, 107s-124s. [CrossRef]

36. Farquharson, C.; Lester, D.; Seawright, E.; Jefferies, D.; Houston, B. Microtubules are potential regulators of growth-plate chondrocyte differentiation and hypertrophy. Bone 1999, 25, 405-412. [CrossRef]

37. Lazarides, E. Intermediate filaments as mechanical integrators of cellular space. Nature 1980, 283, $249-256$. [CrossRef] [PubMed]

38. Traub, P. Intermediate filaments and gene regulation. Physiol. Chem. Phys. Med. NMR 1995, 27, 377-400. [PubMed]

39. Aubin, J.E.; Liu, F.; Malaval, L.; Gupta, A.K. Osteoblast and chondroblast differentiation. Bone 1995, 17 (Suppl. S2), 77s-83s. [CrossRef]

40. Johnstone, B.; Hering, T.M.; Caplan, A.I.; Goldberg, V.M.; Yoo, J.U. In vitro chondrogenesis of bone marrow-derived mesenchymal progenitor cells. Exp. Cell Res. 1998, 238, 265-272. [CrossRef]

41. Temenoff, J.S.; Mikos, A.G. Review: Tissue engineering for regeneration of articular cartilage. Biomaterials 2000, 21, 431-440. [CrossRef]

42. Stockwell, R.A. The cell density of human articular and costal cartilage. J. Anat. 1967, 101 Pt 4, 753-763.

43. Buckwalter, J.A.; Mankin, H.J. Articular cartilage: Tissue design and chondrocyte-matrix interactions. Instr. Course Lect. 1998, 47, 477-486.

44. Nakamura, S.; Arai, Y.; Takahashi, K.A.; Terauchi, R.; Ohashi, S.; Mazda, O.; Imanishi, J.; Inoue, A.; Tonomura, H.; Kubo, T. Hydrostatic pressure induces apoptosis of chondrocytes cultured in alginate beads. J. Orthop. Res. 2006, 24, 733-739. [CrossRef] [PubMed]

45. Akmal, M.; Anand, A.; Anand, B.; Wiseman, M.; Goodship, A.E.; Bentley, G. The culture of articular chondrocytes in hydrogel constructs within a bioreactor enhances cell proliferation and matrix synthesis. J. Bone Jt. Surg. Br. 2006, 88, 544-553. [CrossRef] [PubMed]

46. Buravkova, L.; Romanov, Y.; Rykova, M.; Grigorieva, O.; Merzlikina, N. Cell-to-cell interactions in changed gravity: Ground-based and flight experiments. Acta Astronaut. 2005, 57, 67-74. [CrossRef] [PubMed]

47. Cerwinka, W.H.; Sharp, S.M.; Boyan, B.D.; Zhau, H.E.; Chung, L.W.; Yates, C. Differentiation of human mesenchymal stem cell spheroids under microgravity conditions. Cell Regen. 2012, 1, 2. [CrossRef]

48. Freed, L.E.; Langer, R.; Martin, I.; Pellis, N.R.; Vunjak-Novakovic, G. Tissue engineering of cartilage in space. Proc. Natl. Acad. Sci. USA 1997, 94, 13885-13890. [CrossRef]

49. Kaneko, S.; Satoh, T.; Chiba, J.; Ju, C.; Inoue, K.; Kagawa, J. Interleukin-6 and interleukin-8 levels in serum and synovial fluid of patients with osteoarthritis. Cytokines Cell. Mol. Ther. 2000, 6, 71-79. [CrossRef] 
50. Kamiya, N.; Kuroyanagi, G.; Aruwajoye, O.; Kim, H.K.W. IL6 receptor blockade preserves articular cartilage and increases bone volume following ischemic osteonecrosis in immature mice. Osteoarthr. Cartil. 2019, 27, 326-335. [CrossRef]

51. Aida, Y.; Honda, K.; Tanigawa, S.; Nakayama, G.; Matsumura, H.; Suzuki, N.; Shimizu, O.; Takeichi, O.; Makimura, M.; Maeno, M. IL-6 and soluble IL-6 receptor stimulate the production of MMPs and their inhibitors via JAK-STAT and ERK-MAPK signalling in human chondrocytes. Cell Biol. Int. 2012, 36, 367-376. [CrossRef]

52. Dahlberg, L.; Billinghurst, R.C.; Manner, P.; Nelson, F.; Webb, G.; Ionescu, M.; Reiner, A.; Tanzer, M.; Zukor, D.; Chen, J.; et al. Selective enhancement of collagenase-mediated cleavage of resident type II collagen in cultured osteoarthritic cartilage and arrest with a synthetic inhibitor that spares collagenase 1 (matrix metalloproteinase 1). Arthritis Rheum. 2000, 43, 673-682. [CrossRef]

53. Gao, S.G.; Li, K.H.; Zeng, K.B.; Tu, M.; Xu, M.; Lei, G.H. Elevated osteopontin level of synovial fluid and articular cartilage is associated with disease severity in knee osteoarthritis patients. Osteoarthr. Cartil. 2010, 18, 82-87. [CrossRef]

54. Honsawek, S.; Tanavalee, A.; Sakdinakiattikoon, M.; Chayanupatkul, M.; Yuktanandana, P. Correlation of plasma and synovial fluid osteopontin with disease severity in knee osteoarthritis. Clin. Biochem. 2009, 42, 808-812. [CrossRef] [PubMed]

55. Xu, M.; Zhang, L.; Zhao, L.; Gao, S.; Han, R.; Su, D.; Lei, G. Phosphorylation of osteopontin in osteoarthritis degenerative cartilage and its effect on matrix metalloprotease 13. Rheumatol. Int. 2013, 33, 1313-1319. [CrossRef] [PubMed]

56. Pullig, O.; Weseloh, G.; Gauer, S.; Swoboda, B. Osteopontin is expressed by adult human osteoarthritic chondrocytes: Protein and mRNA analysis of normal and osteoarthritic cartilage. Matrix Biol. 2000, 19, 245-255. [CrossRef]

57. Matsui, Y.; Iwasaki, N.; Kon, S.; Takahashi, D.; Morimoto, J.; Matsui, Y.; Denhardt, D.T.; Rittling, S.; Minami, A.; Uede, T. Accelerated development of aging-associated and instability-induced osteoarthritis in osteopontin-deficient mice. Arthritis Rheum. 2009, 60, 2362-2371. [CrossRef] [PubMed]

58. Akiyama, H.; Lefebvre, V. Unraveling the transcriptional regulatory machinery in chondrogenesis. J. Bone Miner. Metab. 2011, 29, 390-395. [CrossRef] [PubMed]

59. Kozhemyakina, E.; Lassar, A.B.; Zelzer, E. A pathway to bone: Signaling molecules and transcription factors involved in chondrocyte development and maturation. Development 2015, 142, 817-831. [CrossRef]

60. Oh, C.D.; Lu, Y.; Liang, S.; Mori-Akiyama, Y.; Chen, D.; de Crombrugghe, B.; Yasuda, H. SOX9 regulates multiple genes in chondrocytes, including genes encoding ECM proteins, ECM modification enzymes, receptors, and transporters. PLoS ONE 2014, 9, e107577. [CrossRef]

61. Ohba, S.; He, X.; Hojo, H.; McMahon, A.P. Distinct Transcriptional Programs Underlie Sox9 Regulation of the Mammalian Chondrocyte. Cell Rep. 2015, 12, 229-243. [CrossRef]

62. Liu, C.F.; Lefebvre, V. The transcription factors SOX9 and SOX5/SOX6 cooperate genome-wide through super-enhancers to drive chondrogenesis. Nucleic Acids Res. 2015, 43, 8183-8203. [CrossRef]

63. Shi, S.; Wang, C.; Acton, A.J.; Eckert, G.J.; Trippel, S.B. Role of sox9 in growth factor regulation of articular chondrocytes. J. Cell. Biochem. 2015, 116, 1391-1400. [CrossRef]

64. Zhou, G.; Zheng, Q.; Engin, F.; Munivez, E.; Chen, Y.; Sebald, E.; Krakow, D.; Lee, B. Dominance of SOX9 function over RUNX2 during skeletogenesis. Proc. Natl. Acad. Sci. USA 2006, 103, 19004-19009. [CrossRef] [PubMed]

65. Ikegami, D.; Akiyama, H.; Suzuki, A.; Nakamura, T.; Nakano, T.; Yoshikawa, H.; Tsumaki, N. Sox9 sustains chondrocyte survival and hypertrophy in part through Pik3ca-Akt pathways. Development 2011, 138, 1507-1519. [CrossRef] [PubMed]

66. Enomoto, H.; Enomoto-Iwamoto, M.; Iwamoto, M.; Nomura, S.; Himeno, M.; Kitamura, Y.; Kishimoto, T.; Komori, T. Cbfa1 is a positive regulatory factor in chondrocyte maturation. J. Biol. Chem. 2000, 275, 8695-8702. [CrossRef] [PubMed]

67. Takeda, S.; Bonnamy, J.P.; Owen, M.J.; Ducy, P.; Karsenty, G. Continuous expression of Cbfa1 in nonhypertrophic chondrocytes uncovers its ability to induce hypertrophic chondrocyte differentiation and partially rescues Cbfa1-deficient mice. Genes Dev. 2001, 15, 467-481. [CrossRef] 
68. Ueta, C.; Iwamoto, M.; Kanatani, N.; Yoshida, C.; Liu, Y.; Enomoto-Iwamoto, M.; Ohmori, T.; Enomoto, H.; Nakata, K.; Takada, K.; et al. Skeletal malformations caused by overexpression of Cbfa1 or its dominant negative form in chondrocytes. J. Cell Biol. 2001, 153, 87-100. [CrossRef]

69. Jiménez, M.J.; Balbín, M.; López, J.M.; Alvarez, J.; Komori, T.; López-Otín, C. Collagenase 3 is a target of Cbfa1, a transcription factor of the runt gene family involved in bone formation. Mol. Cell. Biol. 1999, 19, 4431-4442. [CrossRef]

70. Hess, J.; Porte, D.; Munz, C.; Angel, P. AP-1 and Cbfa/runt physically interact and regulate parathyroid hormone-dependent MMP13 expression in osteoblasts through a new osteoblast-specific element 2/AP-1 composite element. J. Biol. Chem. 2001, 276, 20029-20038. [CrossRef]

71. Komori, T. Regulation of bone development and extracellular matrix protein genes by RUNX2. Cell Tissue Res. 2010, 339, 189-195. [CrossRef]

72. Sato, M.; Morii, E.; Komori, T.; Kawahata, H.; Sugimoto, M.; Terai, K.; Shimizu, H.; Yasui, T.; Ogihara, H.; Yasui, N.; et al. Transcriptional regulation of osteopontin gene in vivo by PEBP2alphaA/CBFA1 and ETS1 in the skeletal tissues. Oncogene 1998, 17, 1517-1525. [CrossRef]

73. Kamekura, S.; Kawasaki, Y.; Hoshi, K.; Shimoaka, T.; Chikuda, H.; Maruyama, Z.; Komori, T.; Sato, S.; Takeda, S.; Karsenty, G.; et al. Contribution of runt-related transcription factor 2 to the pathogenesis of osteoarthritis in mice after induction of knee joint instability. Arthritis Rheum. 2006, 54, 2462-2470. [CrossRef]

74. Liao, L.; Zhang, S.; Gu, J.; Takarada, T.; Yoneda, Y.; Huang, J.; Zhao, L.; Oh, C.D.; Li, J.; Wang, B.; et al. Deletion of Runx2 in Articular Chondrocytes Decelerates the Progression of DMM-Induced Osteoarthritis in Adult Mice. Sci. Rep. 2017, 7, 2371. [CrossRef] [PubMed]

75. Marlovits, S.; Tichy, B.; Truppe, M.; Gruber, D.; Schlegel, W. Collagen expression in tissue engineered cartilage of aged human articular chondrocytes in a rotating bioreactor. Int. J. Artif. Organs 2003, 26, 319-330. [CrossRef] [PubMed]

76. Aleshcheva, G.; Bauer, J.; Hemmersbach, R.; Egli, M.; Wehland, M.; Grimm, D. Tissue Engineering of Cartilage on Ground-Based Facilities. Microgravity Sci. Technol. 2016, 28, 237-245. [CrossRef]

77. Grimm, D.; Wehland, M.; Corydon, T.J.; Richter, P.; Prasad, B.; Bauer, J.; Egli, M.; Kopp, S.; Lebert, M.; Krüger, M. The effects of microgravity on differentiation and cell growth in stem cells and cancer stem cells. Stem Cells Transl. Med. 2020, 9, 882-894. [CrossRef] [PubMed]

78. Ohyabu, Y.; Kida, N.; Kojima, H.; Taguchi, T.; Tanaka, J.; Uemura, T. Cartilaginous tissue formation from bone marrow cells using rotating wall vessel (RWV) bioreactor. Biotechnol. Bioeng. 2006, 95, 1003-1008. [CrossRef]

79. Luo, W.; Xiong, W.; Qiu, M.; Lv, Y.; Li, Y.; Li, F. Differentiation of mesenchymal stem cells towards a nucleus pulposus-like phenotype utilizing simulated microgravity In vitro. J. Huazhong Univ. Sci. Technol. Med. Sci. 2011, 31, 199. [CrossRef]

80. Yuge, L.; Kajiume, T.; Tahara, H.; Kawahara, Y.; Umeda, C.; Yoshimoto, R.; Wu, S.L.; Yamaoka, K.; Asashima, M.; Kataoka, K.; et al. Microgravity potentiates stem cell proliferation while sustaining the capability of differentiation. Stem Cells Dev. 2006, 15, 921-929. [CrossRef]

81. Wu, X.; Li, S.H.; Lou, L.M.; Chen, Z.R. The effect of the microgravity rotating culture system on the chondrogenic differentiation of bone marrow mesenchymal stem cells. Mol. Biotechnol. 2013, 54, 331-336. [CrossRef]

82. Mayer-Wagner, S.; Hammerschmid, F.; Redeker, J.I.; Schmitt, B.; Holzapfel, B.M.; Jansson, V.; Betz, O.B.; Müller, P.E. Simulated microgravity affects chondrogenesis and hypertrophy of human mesenchymal stem cells. Int. Orthop. 2014, 38, 2615-2621. [CrossRef]

83. Grimm, D.; Wehland, M.; Pietsch, J.; Aleshcheva, G.; Wise, P.; van Loon, J.; Ulbrich, C.; Magnusson, N.E.; Infanger, M.; Bauer, J. Growing tissues in real and simulated microgravity: New methods for tissue engineering. Tissue Eng. Part B Rev. 2014, 20, 555-566. [CrossRef]

84. Krüger, M.; Pietsch, J.; Bauer, J.; Kopp, S.; Carvalho, D.T.O.; Baatout, S.; Moreels, M.; Melnik, D.; Wehland, M.; Egli, M.; et al. Growth of Endothelial Cells in Space and in Simulated Microgravity-A Comparison on the Secretory Level. Cell. Physiol. Biochem. 2019, 52, 1039-1060. [PubMed]

85. Mann, V.; Grimm, D.; Corydon, T.J.; Krüger, M.; Wehland, M.; Riwaldt, S.; Sahana, J.; Kopp, S.; Bauer, J.; Reseland, J.E.; et al. Changes in Human Foetal Osteoblasts Exposed to the Random Positioning Machine and Bone Construct Tissue Engineering. Int. J. Mol. Sci. 2019, 20, 1357. [CrossRef] [PubMed] 
86. Pietsch, J.; Gass, S.; Nebuloni, S.; Echegoyen, D.; Riwaldt, S.; Baake, C.; Bauer, J.; Corydon, T.J.; Egli, M.; Infanger, M.; et al. Three-dimensional growth of human endothelial cells in an automated cell culture experiment container during the SpaceX CRS-8 ISS space mission-The SPHEROIDS project. Biomaterials 2017, 124, 126-156. [CrossRef] [PubMed]

87. Herranz, R.; Anken, R.; Boonstra, J.; Braun, M.; Christianen, P.C.M.; de Geest, M.; Hauslage, J.; Hilbig, R.; Hill, R.J.A.; Lebert, M.; et al. Ground-Based Facilities for Simulation of Microgravity: Organism-Specific Recommendations for Their Use, and Recommended Terminology. Astrobiology 2012, 13, 1-17. [CrossRef]

88. Wuest, S.L.; Richard, S.; Kopp, S.; Grimm, D.; Egli, M. Simulated Microgravity: Critical Review on the Use of Random Positioning Machines for Mammalian Cell Culture. BioMed Res. Int. 2015, 2015, 971474. [CrossRef]

89. Infanger, M.; Ulbrich, C.; Baatout, S.; Wehland, M.; Kreutz, R.; Bauer, J.; Grosse, J.; Vadrucci, S.; Cogoli, A.; Derradji, H.; et al. Modeled gravitational unloading induced downregulation of endothelin-1 in human endothelial cells. J. Cell. Biochem. 2007, 101, 1439-1455. [CrossRef]

90. Riecke, K.; Grimm, D.; Shakibaei, M.; Kossmehl, P.; Schulze-Tanzil, G.; Paul, M.; Stahlmann, R. Low doses of 2,3,7,8-tetrachlorodibenzo- p-dioxin increase transforming growth factor beta and cause myocardial fibrosis in marmosets (Callithrix jacchus). Arch. Toxicol. 2002, 76, 360-366. [CrossRef]

91. Rothermund, L.; Kreutz, R.; Kossmehl, P.; Fredersdorf, S.; Shakibaei, M.; Schulze-Tanzil, G.; Paul, M.; Grimm, D. Early onset of chondroitin sulfate and osteopontin expression in angiotensin II-dependent left ventricular hypertrophy. Am. J. Hypertens. 2002, 15 Pt 1, 644-652. [CrossRef]

92. Grimm, D.; Bauer, J.; Ulbrich, C.; Westphal, K.; Wehland, M.; Infanger, M.; Aleshcheva, G.; Pietsch, J.; Ghardi, M.; Beck, M.; et al. Different responsiveness of endothelial cells to vascular endothelial growth factor and basic fibroblast growth factor added to culture media under gravity and simulated microgravity. Tissue Eng. Part A 2010, 16, 1559-1573. [CrossRef]

93. Szklarczyk, D.; Gable, A.L.; Lyon, D.; Junge, A.; Wyder, S.; Huerta-Cepas, J.; Simonovic, M.; Doncheva, N.T.; Morris, J.H.; Bork, P.; et al. STRING v11: Protein-protein association networks with increased coverage, supporting functional discovery in genome-wide experimental datasets. Nucleic Acids Res. 2019, 47, D607-D613. [CrossRef]

Publisher's Note: MDPI stays neutral with regard to jurisdictional claims in published maps and institutional affiliations.

(C) 2020 by the authors. Licensee MDPI, Basel, Switzerland. This article is an open access article distributed under the terms and conditions of the Creative Commons Attribution (CC BY) license (http://creativecommons.org/licenses/by/4.0/). 